\title{
Altıncı Sınıf Öğrencilerinin Matematiksel Modellemede Oluşturdukları Gerçek Yaşam Problem Durumu Modelleri1
}

\section{Real World Problem Situation's Models Created by 6th Grade Students in Mathematical Modelling}

\author{
Çağlar Naci HIDIROĞLU, Pamukkale Üniversitesi, Eğitim Fakültesi, chidiroglu@pau.edu.tr \\ Yeliz ÖZKAN HIDIROĞLU, Milli Eğitim Bakanlığı, yelizozkan09@gmail.com
}

\begin{abstract}
öZ. Çalışmanın amacı, altıncı sınıf öğrencilerinin matematiksel modellemede oluşturdukları gerçek yaşam problem durumu modellerinin incelenmesidir. Temel nitel araştırma anlayışıly yürütülen çalışmanın katılımcıları, Denizli'de ortalama başarıya sahip, daha önce modelleme uygulaması yapılmamıș üç ortaokulda öğrenim gören 64 altıncı sınıf öğrencisidir. Nitel veriler dört farklı matematiksel modelleme problemine ilişkin yazılı yanıt kağıtlarından, araştırmacıların çözüm sürecinde aldıkları gözlem notlarından olușturulmuştur. Nitel veri analizinde içerik analizinden yararlanılmıştır. Gerçek modeller resim, şekil ve tablo/liste türündedir. Modelin oluşturulmasında deneyim, anlama, tahmin/ölçüm ve matematiksel bilgi etkilidir. Gerçek modeller matematiksel çözüm/sonuçlara ulașma ve yorumlama amacıyla kullanılmıștır. Öğrenciler çcözümde zihinsel modellerini gerçek yaşam problem durumu modellerine yansıtamamışlar, modellerinde çözüm için gereksiz çizimlere yer vermişler, gerekli stratejik etkenleri belirleyemediklerinden dolayı nitelikli modeller oluşturamamışlardır. Öğrenciler uzunluk, ağırlık gibi kavramları karıştırdıkları ve hatalı tahminlerde bulundukları için gerçekçi bir model elde edememişlerdir. Öğrencilerin modelleri üzerinden yüzeysel işlem/yorumlar yapmaları onların ilerleyen basamaklarda beklenen düzeyde başarılı olmalarını engellemiştir. Mikro düzeyde modelleme anlayışıyla, öğrencilerin modellemede gerçek modelleri oluşturma sürecindeki yeterlikleri geliştirilmelidir.
\end{abstract}

Anahtar Sözcükler: Matematiksel Modelleme, Altıncı Sınıf Öğrencisi, Gerçek Yaşam Problem Durumu Modeli

\begin{abstract}
The purpose of the study is to examine real world problem situation's models created by 6th grade students in mathematical modelling. The study, which was designed as the basic qualitative design, consisted of 64 middle school students who have not attended any modelling activities from three moderately successful schools in Denizli. Qualitative data were collected with the help of written answer sheets given to modelling problem, and the observation notes which were taken by the researchers during the study. In the qualitative data analysis, content analysis was utilized. Real models were presented as pictures, figures, tables/lists. In developing model, experience, understanding, prediction/measurement and mathematical knowledge were effective. Real models were used for the purpose of obtain to mathematical solution/result and interpretation. Students couldn't reflect their mental models to real world problem situation's models, also they included unnecessary drawings in the solutions and their models, and they couldn't create qualified models because of not identifying required strategic factors. Students couldn't create realistic models because of mixing up the concepts such as length and weight and having incorrect guesses. An obstacle for students in getting expected success in later steps was having superficial operations or interpretations. With atomistic approach, the competencies of students in developing real models in modelling should be developed.
\end{abstract}

Keywords. Mathematical Modelling, $6^{\text {th }}$ Grade Students, Real World Problem Situation's Model

\section{SUMMARY}

Purpose and Significance: The purpose of the study is to explain the real world problem situation structures developed by 6th grade students, and also to reveal the positive and negative factors affecting to development of these models and how these models are used in the process. As the difficulty faced by students in developing mathematical models may be arisen from mathematics, the structure and the effectiveness of the real world problem situation's models developed by the students have also a great importance in the structure of mathematical models and the success of the solution (Blum, 2011; Borromeo Ferri, 2006; 2007; Hıdıroğlu, 2015). Besides, when the relations among Turkish success level in PISA, education level of students taking PISA, modeling and PISA problems; the modeling competencies of middle school students, age group of 15, in Turkey may be 
said that not at the adequately expected level despite the importance of modeling in curriculum. Because of the 6th grade is a key process in transferring to abstract thinking period and important period in acquiring the necessary competencies in transition from real world to mathematics, the study aims to reveal the structure of the real world problem situation's models, factors affecting and its effect to the process of 6 th grade students.

Methodology: The study, which was designed as the basic qualitative design, consisted of 64 middle school students who have not attended any modelling activities from three moderately successful schools in Denizli. Qualitative data were collected with the help of written answer sheets given to modelling problems [Straw Bails Problem (Borromeo Ferri, 2007), School Size Problem, Saving Water Problem (Learning and Education in and through Modelling and Applications [LEMA], 2009), School Parking Problem (LEMA, 2009)], and the observation notes which were taken by the researchers during the study. The data collection process of the study is as follows: 1) Determine Schools: Firstly, the middle schools which have the moderate success in the exams which are held city-wide were determined. Based on the administrators and teachers' willingness, three schools were chosen out of these schools in scope of the study. Also, the situation of having no previous modelling applications due to any project or workshops carried out before in these schools is also checked. In this respect, it was aimed to reveal the general levels and approaches of the students in this process. 2) Determine Classes: By contacting with the teachers, and requesting from them to choose a moderate class by keeping in mind the willingness of students to attend the application. In this line, 3 classes consisting of 64 students were chosen. 3) Application: It was requested from students to solve four mathematical modelling problems individually without getting help from teachers and with having no time limit in the mathematics course at one class of 3 different middle schools. At the end of data collection process, 64 pages of written answer sheets, and 17 pages of observations notes which were taken during the solution process by two researchers separately were subjected to data analysis. In the qualitative data analysis, content analysis was utilized. The paths followed in the data analysis process are given below.1) Data coding 2) Determining temporary categories 3) Adapting codes to categories 4) Finalizing temporary categories 5) Determining the general characteristics of the categories 6) Determining the differences between the categories 7) Organizing findings in line with the study's purpose and codes and categories obtained. As stated by Strauss and Corbin (1990), coding based on theoretical framework out of three different types of coding was employed. In this respect, the required coding and categorizing in the study were performed by considering the main components, steps and characteristics of mathematical modelling process proposed by Hidıroğlu (2015), and different types of representations explained by Diezmann and English (2001), Elia, Gagutsis and Demetriu, 2007, Neria and Amit (2004), Preston and Garner (2003). In the process of data analysis, inter coder reliability formula (Miles \& Huberman, 1994) was used and reliability between two coders was calculated as $92 \%$.

Results: In the table obtained as a result of data analysis, the situation of categories encountering in 264 different solutions by considering the problems' types were given as frequencies and percentages. Encountering with codes and categories frequency values in Table 1 were interpreted when needed in the related sections while explanations were given in the findings. Real models were presented as pictures, figures, tables/lists. In developing model, experience, understanding, prediction/measurement and mathematical knowledge were effective. Real models were used for the purpose of mathematical solution/result and interpretation. Students couldn't reflect their mental models to real world problem situation's models, also they included unnecessary drawings in the solutions and their models, and they couldn't create qualified models because of not identifying required strategic factors. Students couldn't create realistic models because of mixing up the concepts such as length and weight and having incorrect guesses. An obstacle for students in getting expected success in later steps was that having superficial operations or interpretations. With atomistic approach, the competencies of students in developing real models in modelling should be developed. 


\begin{tabular}{|c|c|c|c|c|c|c|c|c|}
\hline & & \multirow{2}{*}{ PROBLEMS } & \multicolumn{4}{|c|}{ MODELLING PROBLEMS } & \multirow{2}{*}{$\begin{array}{c}\text { Total } \\
\text { Frequency } \\
T(n) \\
\end{array}$} & \multirow[b]{2}{*}{$\begin{array}{c}\text { Percentage } \\
(\%)\end{array}$} \\
\hline \multicolumn{2}{|l|}{ CATEGORIES } & & $\begin{array}{c}\text { Straw } \\
\text { Bails }\end{array}$ & $\begin{array}{c}\text { School } \\
\text { Size }\end{array}$ & $\begin{array}{c}\text { Water } \\
\text { Wasting }\end{array}$ & Parking & & \\
\hline \multirow{5}{*}{$\begin{array}{l}\text { Factors Affecting } \\
\text { the Structure of } \\
\text { Real World } \\
\text { Problem } \\
\text { Situation's Model }\end{array}$} & $\begin{array}{l}\text { Problem } \\
\text { Based }\end{array}$ & 1) Problem Content & - & - & - & - & - & - \\
\hline & \multirow{4}{*}{$\begin{array}{l}\text { Student } \\
\text { Based }\end{array}$} & 1) Understanding Problem & 27 & 47 & 46 & 41 & 161 & 63 \\
\hline & & 2) Real Life Experiences & 11 & 44 & 49 & 30 & 134 & 52 \\
\hline & & 3)Prediction/Measurement & 20 & 47 & 47 & 38 & 152 & 59 \\
\hline & & $\begin{array}{l}\text { 4)Mathematical Prior } \\
\text { Knowledge }\end{array}$ & 30 & 44 & 43 & 26 & 143 & 56 \\
\hline \multirow{3}{*}{\multicolumn{2}{|c|}{$\begin{array}{l}\text { Type of Real World Problem } \\
\text { Situation's Model }\end{array}$}} & 1) Picture & 24 & 0 & 3 & 19 & 46 & 18 \\
\hline & & 2) Figure & 12 & 0 & 0 & 17 & 29 & 11 \\
\hline & & 3) Table/List & 5 & 47 & 46 & 5 & 103 & 40 \\
\hline \multirow{3}{*}{\multicolumn{2}{|c|}{$\begin{array}{l}\text { Use of Real World Problem } \\
\text { Situation's Model in Modelling } \\
\text { Process }\end{array}$}} & $\begin{array}{l}\text { 1) Reaching Mathematical } \\
\text { Solution }\end{array}$ & 18 & 16 & 15 & 23 & 72 & 28 \\
\hline & & $\begin{array}{l}\text { 2) Reaching Mathematical } \\
\text { Results }\end{array}$ & 2 & 9 & 5 & 2 & 18 & 7 \\
\hline & & 3) Interpreting & 9 & 11 & 7 & 12 & 39 & 15 \\
\hline
\end{tabular}

Discussion and Conclusion: Students have difficulties especially more in Hay Bale Problem which is far more remote from real life experiences. Maa $\beta$ (2006) and Lesh and Caylor (2007) stated that students more easily comprehend situations based on real world knowledge and experiences and this is an important factor for students to get more realistic models and solutions. Students couldn't understand the problem exactly in that problem and because of the fact that they couldn't make a connection between mathematics and real world, they haven't been able to use ratio concept even they have already knew it. Students couldn't make realistic predictions even though they have tried to make predictions on the strategic factors that would create realistic models. Students took the way of reaching the real model and mathematical solution with unjustified predictions and had difficulties in explaining their mathematical thinking in modelling. Maaß $(2005,2006)$, Kaiser (2007) and Blum (2011) also acknowledged that students don't consider reality in making predictions and can't get closer to the real values in the predictions on strategic factors which were not given directly in the problem and thus all of these influence their real models in mathematical modelling. Students couldn't reflect mental models to real world problem situation's models fully and included unnecessary drawings for the solution in the real models. As parallel to Crouch and Haines (2004), Ikeda and Stephens (2001), Ji (2012) and Niss (2001), it has been determined that students have difficulties in transition, which includes understanding problem, simplification and prediction processes, from real world to mathematics. As Montegue (2008) also stated, real world problem situation's models occur in two different types in the study, table/list and picture and figure. Picture occurred as external representation of how students remembered the real world situation first in his/her mind, while figure occurred as meaningful external representation of real world problem situation created by students by considering their task and knowledge. In further studies, the effect of mental model in modelling process on modelling, the relationship between mental models (internal representation) and real world problem situation's models (external representation) and the effect of internal and external representations onto each other might be revealed via clinical interviews. In this respect, the effect of learning activities which are designed in line with the atomistic and holistic approaches in respect to required modelling competencies related with representations on students gaining required competencies may be examined with mixed method research. The effect of various representations which may be given with modelling problem in generating other representation types in the process and mental processes in modelling may also be examined.

\section{GíRiş}

Eğitimde temsiller, öğrencilerin zihinsel süreçlerini ve ürünlerini açığa çıkaran, zenginleştiren (Eisner, 1997) ve kavramsal ilişkileri ortaya çlkararak kavramsal öğrenmeyi destekleyen (National Council of Teachers of Mathematics [NCTM], 2000) önemli araçlardan biridir. Brenner, Mayer, Moseley, Brar, Durán, Reed ve Webb (1997) ve Fennell ve Rowan (2001) temsillerin farklı 
düşünmeye fırsat sağladığını ve Bloom'un yeni taksonomisindeki üst basamaklarda yer alan analiz, değerlendirme ve yaratmadaki üst düzey düşünme becerilerini geliştirdiğini vurgulamaktadır. Türkiye'deki ortaokul matematik dersi öğretim programında matematik eğitiminin genel amaçlarından biri, öğrencilerin kavramları farklı temsil biçimleri ile ifade edebilmelerini sağlayacak öğrenme ortamlarının oluşturulmasıdır (Milli Eğitim Bakanlığı [MEB], 2013). Öğretim programında temel becerilerden biri olarak ele alınan ilişkilendirmedeki alt becerilerden ikisi, matematiksel kavram ve kuralları farklı temsil biçimleriyle gösterme ve onların farklı temsil biçimlerini birbiriyle ilişkilendirme/birbirine dönüştürmedir. Öğretim programı incelendiğinde, öğrenme sürecinde temsilin önemine vurgu yapıldığı halde, problem çözme sürecindeki etkisine yönelik açıklamaların yapılmadığı görülmektedir. Halbuki temsiller eğitimde kavramsal anlama sürecinde etkili bir araç olarak kullanıldığı gibi öğrencilerin problem çözme süreçlerinde de büyük önem taşımaktadır.

\section{Problem Çözmede Temsiller}

Matematik eğitiminde temsiller, özellikle problem çözme sürecinde iletişim, ilişkilendirme ve akıl yürütme aracı olması bakımından önemli yere sahiptirler. Fennell ve Rowan (2001), temsillerin problemin analizinde ve problemlere ilişkin farklı çözüm yolları üretmede büyük önem taşıdıklarını ifade etmektedir. Greeno ve Hall (1997), problem çözme sürecinde problemi anlayan öğrencilerin temsillerden yararlandıklarını ve süreçte oluşturdukları bu temsillerin ise öğrencilerin problem ile ilgili anlayışlarını geliştirdiğini vurgulamaktadır. Cifarelli (1998) de problem çözmede başarının büyük oranda probleme uygun temsilleri oluşturmayla ilgili olduğunu ve öğrencilerin temsiller yardımıyla bilgiyi ve ilişkileri daha iyi anladıklarını belirtmektedir.

Alanyazın incelendiğinde, araştırmalarda (Cai, 2005; Goldin ve Shteingold, 2001; Janvier ve Bednarz, 1987) genellikle temsillerin içsel ve dışsal olmak üzere iki farklı türünden söz edilmektedir. İçsel temsiller, bir durum veya olayın zihindeki gösterimleri veya zihinsel modelleri iken; dışsal temsiller, zihinsel modellerin görsel veya sembolik hale getirilmesiyle elde edilen modellerdir. Buna göre, içsel temsillere ulaşmak oldukça zor olduğu gibi onu temsil eden dışsal temsiller zihinsel modellerle ilgili önemli ipuçları sağlamaktadır. Cai ve Lester (2005), problem çözme sürecinde başarılı olan öğrencilerin ortak özelliklerinin içsel ve dışsal temsilleri oluşturan ve bunları doğru yerlerde kullanabilen kişiler olduklarını ifade etmektedir. Cox (1999), öğrenmede dışsal ve zihinsel olmak üzere iki farklı temsilin varlığından söz etmektedir. Ona göre, temsilin bilişsel ve anlamsal niteliği, görevin (problem durumu gibi) istedikleri, görevle ilgili önceki bilgiler ve stratejiler temsilin yapısını etkileyen üç temel faktördür. Lesh, Post ve Behr (1987) daha çok dışsal temsillere vurgu yaptıkları çalışmada, beş farklı temsil türünden bahsetmektedir. Bunlar; durağan resimler, yazılı semboller, somut nesneler, konuşma dili ve gerçek yaşam durumlarıdır. Alanyazında bazı çalışmalar (Diezmann ve English, 2001; Elia, Gagutsis ve Demetriu, 2007; Neria ve Amit, 2004; Preston ve Garner, 2003) herhangi bir üst kategorilendirmeye gitmeden, oluşturulabilecek farklı temsilleri; tablo, resim, sayısal, cebirsel, diyagram, grafik ve sembolik gibi farklı türlere ayırmaktadır. Montegue (2008) öğrencilerin oluşturdukları farklı temsilleri incelediği çalışmasında, resim ve şekil arasındaki farka önemli bir vurgu yapmaktadır. Ona göre, resim öğrencilerin gerçek yaşamdaki bir durumu zihinde ilk hatırladığı haliyle dışsal temsil haline getirmesidir. Fakat şekil, öğrencilerin görev ve bilgilerini dikkate alarak gerçek yaşam durumunu anlamlı bir şekilde dışsal temsil haline getirmesini gerektirmektedir. Bir başka ifadeyle, öğrenciler tarafından oluşturulan resimler görev için çok uygun olmayan ve yeni bilgileri dikkate almayarak geçmiş deneyim ve bilgilerle elde edilen, düşük düzeyde düşünme süreçlerini içeren bir süreçtir. Problem çözmede başarılı olan öğrenciler, dışsal temsil olarak resim değil şekilleri kullanmaktadırlar. Matematiksel problemleri temsil etmede zorlanan öğrenciler ise genellikle resimler çizmekte ve sürecin ileriki basamaklarına geçememektedirler. Bu öğrencilerin problem temsil stratejileri zayıftır. Bunun yanında, temsilleri olușturup ileriki basamaklarda ise temsili gerektiği gibi kullanamayan öğrenciler de problem çözme sürecinde başarısız olmaktadır (Montegue, 2008). Günümüzde önemli ve özel bir problem çözme sürecini açığa çıaran matematiksel modelleme problemlerinde de temsiller önemli roller üstlenmekte ve zihinsel eylemleri desteklemektedir. 


\section{Matematiksel Modelleme}

21. yy'da gelişmiş ülkelerin öğretim programları incelendiğinde kendisine yer bulan ve özel bir problem çözme sürecini açıklayan matematiksel modelleme, en temelde Dewey, Pólya ve Piaget gibi önemli araştırmacıların düşünceleri ile eğitim alanında önemli bir kavram olmaya başlamıştır. Matematiksel modelleme, 1970'lerde birçok gelișmiş ülkenin öğretim programlarına entegre edilmeye başlamış ve matematik eğitiminde öğrencilere kazandırılması beklenen temel becerilerden birisi olarak ele alınmıştır. Matematiksel modelleme, doğası gereği gerçek yaşamdaki problem durumlarını ele aldığından dolayı sınırlandırılmadığı sürece çözüm sürecinde matematik, fizik, kimya veya biyoloji alanındaki bilgilerden yararlanmayı gerektirmektedir. Bu yönüyle disiplinlerarası bir süreci açığa çıkaran modelleme, günümüzde daha zengin zihinsel süreçlerin açığa çıkarılması ve modelleme yeterliklerinin kapsamlı bir şekilde belirlenerek daha nitelikli çözümlere fırsat verecek daha etkili problem çözme süreçlerinin yaratılması için eğitimde önemli bir araç konumundadır (Hıdıroğlu, 2015).

Matematiksel modelleme ile ilgili çalışmalar kategorilendiğinde (Blomhøj, 2008; Kaiser, 2005; Kaiser ve Sriraman, 2006), matematiksel modelleme sürecindeki zihinsel süreçlere ve zihinsel ilerleyişinin yapısına odaklanan bilişsel modelleme çalışmaları karşımıza çıkmaktadır. Borromeo Ferri (2007) bilişsel modelleme çalışmalarının 2000'li yıllara kadar ihmal edildiğini ifade ederek, modelleme sürecinde öğrencilerin başarılı olabilmesi için gerekli yeterliklerin ortaya çıkarılmasına ve bu yönde öğrencilerin geliştirilmesine vurgu yapmaktadır. Bilișsel modelleme çalışmaları incelendiğinde, ilk çalışmaların genellikle temel basamakları açıkladığı, daha sonrakilerin temel basamak ve bileşen ayrımı yapmadan süreci biraz daha ayrıntılandırmaya çalıştığı ve daha sonrakilerin de temel basamak ve bileşen ayrımını gözeterek süreci açıkladığı görülmektedir (Hıdıroğlu, 2012). Son zamanlarda yapılan bazı araştırmalar (Blum ve Leiß, 2007; Borromeo Ferri, 2006; 2007; 2010; Galbraith ve Stillman, 2006; Hıdıroğlu, 2012; 2015; Saeki ve Matsuzaki; 2011; 2013) temel basamak, temel bileşen, alt basamak bazında daha kapsamlı olarak modelleme sürecini açıklamıştır. Bazıları sürece teknolojiyi de entegre etmiştir (Ang, 2001; 2006; 2010; Galbraith ve Stillman, 2006; Galbraith, Stillman, Brown ve Edwards, 2007; Hıdıroğlu ve Bukova Güzel, 2013; 2014; 2016; 2017; Hıdıroğlu, 2015; Lingefjärd, 2012). Bazıları (Hıdıroğlu ve Bukova Güzel, 2015; 2016; Hıdıroğlu, 2015; Maaß, 2006; Magiera ve Zawojevski, 2011; Zawojewski ve Lesh, 2003) da biliş ve üst bilişi modelleme sürecinde dikkate almıştır. Bu çalışmalar incelendiğinde, modelleme sürecinde çok farklı temsillerin açığa çıktığı ve temsillerin zihinsel eylemleri etkilediği görülmektedir.

\section{Matematiksel Modellemede Temsiller}

Matematiksel modelleme sürecinde ileriki basamaklara geçebilmek için birçok farklı temsilin kullanıldığı ve bu temsillerden bazılarının ise modeller olduğu görülmektedir (bkz. Şekil 1). Modelleme sürecindeki temel bileşenlerden üçü olan ve gerçek yaşam problem durumunun modeli, yardımcı matematiksel model ve ana matematiksel model olarak karşımıza çıkan temsiller modellemede nitelikli bir çözümün gerçekleştirilmesinde büyük bir rol üstlenmektedirler. 


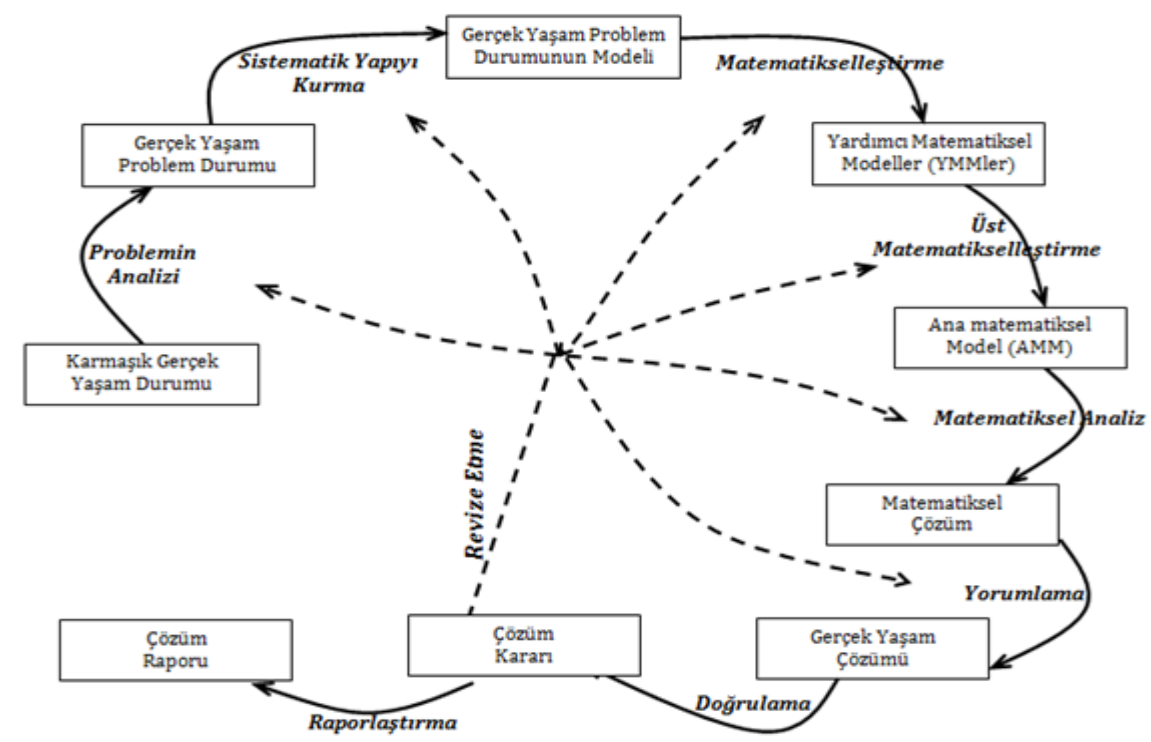

Şekil 1. Matematiksel modelleme süreci (Hıdıroğlu, 2015)

Matematiksel model, gerçek durumları, eylemleri ve süreçleri temsil eden matematiksel tekniklerden yararlanarak ve matematiksel notasyonlara bağlı kalınarak oluşturulmuş sembolik temsillerdir (Stark ve Nichols, 2005). Gerçek yaşam problem durumunun modeli ise, öğrencilerin gerçek yaşamdan matematiksel dünyaya geçmelerini sağlayan önemli bir köprü vazifesi gören, matematiksel modellerin oluşturulması için temel teşkil eden ve tablo, şekil, resim, liste gibi farklı şekillerde karşımıza çıkabilen temsillerdir (Hıdıroğlu, 2015). Matematiksel modelleme sürecinde gerçek yaşam problem durumunun modeli diğer temsillere ulaşmada büyük önem taşımaktadır. Kaiser (2007), modellemedeki yeterlikleri beş temel kategoride ele almaktadır. Kaiser'e (2007) göre gerçek yaşam modeli, bu beş yeterliğin hepsinde önemli bir araç olarak kullanılmaktadır. Özellikle gerçek yaşamdan matematiksel dünyaya geçişte ve ileriki basamaklarda da matematiksel dünyadan gerçek yaşama geçişte önemli bir köprü vazifesi görmektedir. Blum ve Leiß (2007) de gerçek modeli modelleme sürecinin en önemli bileșenlerinden biri olarak görmekte ve modelleme yeterliklerinde başarı düzeylerini açıklarken gerçek modeli oluşturamayan öğrencilerin modellemede 6 düzeyden 3. düzeye çıkamadıklarını vurgulamaktadır. Borromeo Ferri (2006), modelleme sürecini açılklarken gerçek modelin ikinci basamakta ulaşılması beklenen önemli bir bileşen olduğunu belirtmektedir. Borromeo Ferri (2007) ve Blum ve Leiß (2007) tarafından "real model" olarak ifade edilen gerçek yaşam problem durumunun modeli, öğrencilerin gerçek yaşam problem durumunu deneyimlerini (gerçek yaşam problem çözme) ve matematiksel bilgi ve becerilerini kullanarak üst düzey varsayımlarla oluşturdukları modellerdir. Bu modeller bir bakıma öğrencilerin zihinsel modellerini bazı yönleriyle temsil ettiği gibi onların problemi çözebilecekleri hale getirmeleriyle daha sınırlı bir zihinsel yapı haline gelebilmektedir. Hıdıroğlu (2015) da modelleme sürecinin ikinci basamağı olan "Sistematik Yapıyı Kurma" basamağında gerçek yaşam problem durumunun modeline öğrencilerin ulaşması gerektiğini ifade etmekte ve bu modelin gerçek yaşamdaki durumu matematikselleştirmelerinde büyük önem taşıdığını vurgulamaktadır. Farklı modelleme süreçlerinde (Blum, 1985; 1996; 2011; Blum ve Leiß 2007; Borromeo Ferri, 2006; 2007; Hıdıroğlu 2015; Kaiser Meßmer, 1986; Maki ve Thompson, 2010; Saeki ve Matsuzaki, 2013; Schwarz, Wissmach ve Kaiser, 2008; Tatsis, 2010; Verschaffel, De Corte ve Borghart, 1997) farklı șekillerde isimlendirilse de gerçek yaşam problem durumu modeli sürecin önemli bileșeni olarak karşımıza çıkmaktadır. Bu temsil, matematiksel model ile birlikte modelleme sürecindeki dünyalar (gerçek yaşam ve matematik) arasındaki geçişte başrol oynamaktadır. Hıdıroğlu'na (2015) göre, öğrencilerin modelleme yeterlikleri ve çözüm için gerekli bilgileri (matematik, gerçek yaşam vd.) ne kadar üst düzeydeyse oluşturdukları zihinsel modelleri ile gerçek yaşam problem durumu modelleri yapısal olarak birbilerine çok yakın olmaktadır (bkz. Şekil 2). Öğrencilerin matematiksel modelleri oluşturmalarındaki zorluk matematik kaynaklı olabileceği gibi, öğrencilerin oluşturdukları gerçek yaşam problem durumu modellerinin yapısı ve etkililiği de matematiksel modellerin yapısında ve 
çözümün başarısında büyük önem taşımaktadır (Blum, 2011; Borromeo Ferri, 2006; 2007; Hıdıroğlu, 2015).

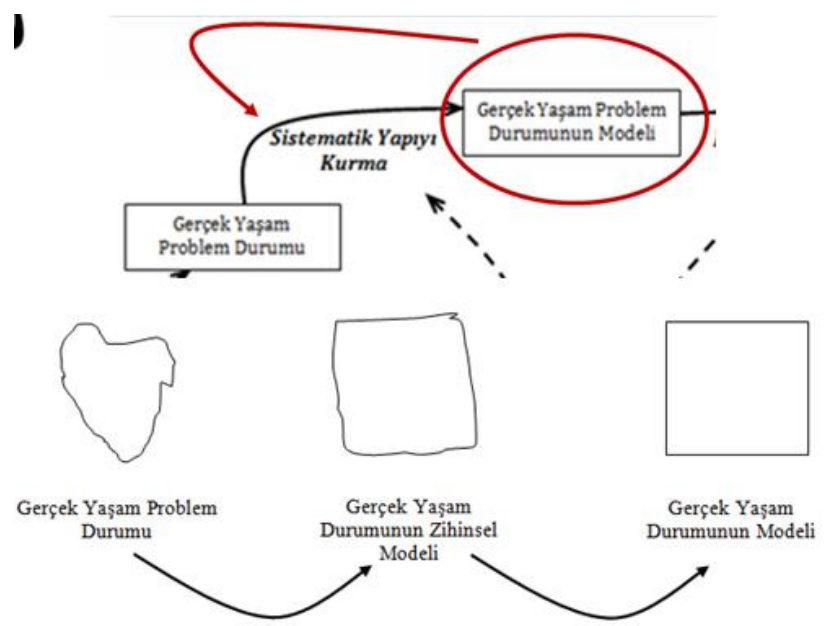

Şekil 2. Zihinsel model ve gerçek yaşam problem durumunun modeli arasındaki ilişski (Hıdıroğlu, 2015)

Ülkelerin 15 yaşındaki öğrencilerinin katıldığı OECD tarafından hazırlanan PISA sınavı raporları incelendiğinde, Türkiye, matematik sınavında OECD ülkeleri arasında sondan ikinci, 70 ülke arasından ise 49. sırada bulunmaktadır (Organisation for Economic Co-operation and Development [OECD], 2016). 2016 OECD raporlarında 5. ve 6. düzeyde (PISA'da en üst iki seviye) \%1.6 öğrencimiz varken; 2. düzeyin altında (0. ve 1. düzey) kalan öğrenci yüzdesi \%31.6 olarak belirlenmiștir. 5. ve 6. seviyedeki öğrenci yüzdesinde Türkiye 60. sırada yer almaktadır. Bu durum, öğrencilerin PISA sınavlarında onlara yöneltilen sorularda diğer ülkelere göre oldukça başarısız bir performans sergilediklerini ve PISA'da en üst düzeyde başarı gösterebilen öğrenci sayısının oldukça az olduğunu göstermektedir. Ayrıca, Türkiye'deki öğrencilerin düzey 0 ve düzey 1 'de bir yığılması söz konusudur. OECD (2016) raporu verileri 2003, 2006, 2009 ve 2012'da yapılan PISA sinavi verileriyle karşılaştırıldığında da matematikten alınan puanlarda bir düşüş olduğu görülmektedir.

OECD (2003) PISA 2003 raporunda açılanan 6 seviyelik yeterlik düzeyleri incelendiğinde, gösterim biçimleri düzey 2'den itibaren öğrencilerden beklenen önemli bir yeterlik olarak görülmektedir. Aynı zamanda Turner'ın (2007) ifade ettiği gibi, PISA'daki problemlerin birçoğu tam bir matematiksel modelleme problemi düzeyinde olmasa da modelleme sürecinin bazı evreleriyle doğrudan ilişkilidir ve soruların güçlük düzeyi de modelleme basamaklarını içerme seviyesiyle orantılı biçimde artmaktadır. Bu yönüyle öğrencilerin uluslararası sınavlarda ve proje çalışmalarında başarılarının arttırılması için öğrencilerin matematiksel modelleme problemleriyle başbaşa kalacağı zengin ortamların yaratılması büyük önem taşımaktadır (Turner, 2007).

PISA'da Türkiye'nin başarı düzeyi, PISA'ya giren öğrencilerin eğitim düzeyleri, modelleme ve PISA problemleri arasındaki ilişki düşünüldügünde, Türkiye'de 15 yaş grubu altında yer alan ortaokul düzeyindeki öğrencilerin modelleme yeterliklerinin, modellemenin öğretim programlarındaki önemine rağmen, beklenen düzeyde olmadığı söylenebilir. Altıncı sınıf döneminin soyut döneme geçişte önemli bir süreç olması ve modelleme sürecindeki gerçek yaşamdan matematiğe geçiş için gerekli yeterlikleri kazandıracak önemli bir dönem olması nedeniyle çalışma, altıncı sınıf öğrencilerin gerçek yaşam problem durumu modeli ve bu süreçteki modelleme yeterliklerini açığa çıkarmayı hedeflemiştir.

Çalışmada altıncı sınıf öğrencilerinin oluşturdukları gerçek yaşam problem durumu modellerinin yapısı açıklanmış, bu modelleri oluşturmalarına etki eden olumlu ve olumsuz faktörler belirlenmiş ve bu modellerin süreçte nasıl kullanıldıkları açığa çıkarılmıştır. Bu sayede altıncı sınıf öğrencilerinin bu tür yeterliklerinin düzeyleri de belirlenmiştir. Bu doğrultuda çalışmanın amacı, altıncı sınıf öğrencilerinin matematiksel modelleme sürecinde oluşturdukları gerçek yaşam problem durumu modellerinin incelenmesidir. Araștırmanın problem cümlesi "Altıncı sınıf öğrencilerinin matematiksel modellemede oluşturdukları gerçek yaşam problem durumu modellerinin yapısı nasıldır ve bu modeller süreci nasıl etkilemektedir?" şeklinde ifade edilmiştir. Bulguların sunumunda dikkate alınan alt problemler ise aşağıda verilmiştir. 
1) Altıncı sınıf öğrencilerinin modelleme sürecinde oluşturdukları gerçek yaşam problem durumu modellerinin yapısını etkileyen faktörler nelerdir?

2) Altıncı sınıf öğrencilerinin modelleme sürecinde oluşturdukları gerçek yaşam problem durumu modellerinin türleri nelerdir?

3) Altıncı sınıf öğrencilerinin modelleme sürecinde oluşturdukları gerçek yaşam problem durumu modelleri süreçte nasıl kullanılmaktadır?

\section{YÖNTEM}

\section{Araştırmanın Modeli}

Araștırma, nitel bir anlayıș ile yürütülmüș temel nitel araştırma çalışmasıdır. Temel nitel araştırma çalışmaları herhangi bir durumu ve süreci açıklayarak, bir sürecin nasıl gerçekleştiğini ve gerçeğin meydana gelmesinde nasıl bir yol izlendiğini ortaya çıkarmayı amaçladığı (Merriam, 2013) için bu anlayıșın araştırmanın amacına ulaşmada daha iyi hizmet edeceği düşünülmüştür. Bu sayede modelleme sürecinin belli bir aşamasında oluşturulan gerçek yaşam problem durumu modellerinin yapısı, onu etkileyen etmenler ve bu modellerin süreci nasıl etkilediği açıklanmaya çalışılmıştır.

\section{Katılımcilar}

Araştırmanın katılımcıları, 2015-2016 eğitim ve öğretim yılında Denizli ilindeki üç ortaokulda öğrenim gören 64 altıncı sınıf öğrencisidir. Katılımcı grubun seçiminde amaçlı örnekleme yöntemlerinden biri olan ölçüt örnekleme yönteminden yararlanılmıştır. Bu doğrultuda, daha önce herhangi bir proje, çalıştay benzeri çalışmalar kapsamında matematiksel modelleme uygulamaları yapılmamış olan ve Denizli ilinde ortalama başarıya sahip üç ortaokulun yine ortalama başarıdaki üç şubesi seçilmiştir. Bu sayede elde edilecek bulgular ile var olan genel durumu yansıtabilecek ortamlar hazırlanmaya çalışılmıştır.

Araştırmanın amacı ve kapsamı doğrultusunda çalışmada, okulların ve şubelerin belirlenmesinde belirlenen ölçütlerle (il geneli sınavda ortalama başarı, okul başarısı ile aynı düzeyde şube, isteklilik) ortalama düzeydeki durumları yansıtacak ve ortalama düzeyde görülebilecek tipik eksikliklere yönelik bazı açıklamalar getirilebilecek (Patton, 1987) ortamlar yaratılmaya çalışılmıştır.

\section{Veri Toplama Araçları}

Araștırmanın verileri, öğrencilerin dört farklı matematiksel modelleme problemine (Saman Balyası Problemi, Okul Mevcudu Problemi, Su Harcama Problemi, Otopark Problemi) ilişkin çözümlerini içeren yazılı yanıt kağıtlarından ve araştırmacıların çözüm sürecinde aldıkları gözlem notlarından derlenmiştir. Araştırmada Aiken (1997) ve Punch'ın (2013) sinıflandırmasında kendisine yer bulan yarı yapılandırılmış gözlem tekniğinden yararlanılmıştır. Gözlem notları alınırken Hıdıroğlu'nun (2015) süreç modelindeki temel basamaklar ve temel bileşenler dikkate alınmış, öğrencilerin sergiledikleri yaklaşımlara ve düşüncelere odaklanılmıștır. Yazılı yanıt kağıtları, Merriam'ın (2013) sınıflandırmasındaki araștırma sırasında üretilen dokümanlara girmekte olup öğrencilerin onlara yöneltilen modelleme problemlerine verdikleri yazılı raporları içermektedir. Araștırmada kullanılan matematiksel modelleme problemlerine Şekil 3, 4, 5 ve 6'da yer verilmiștir. 


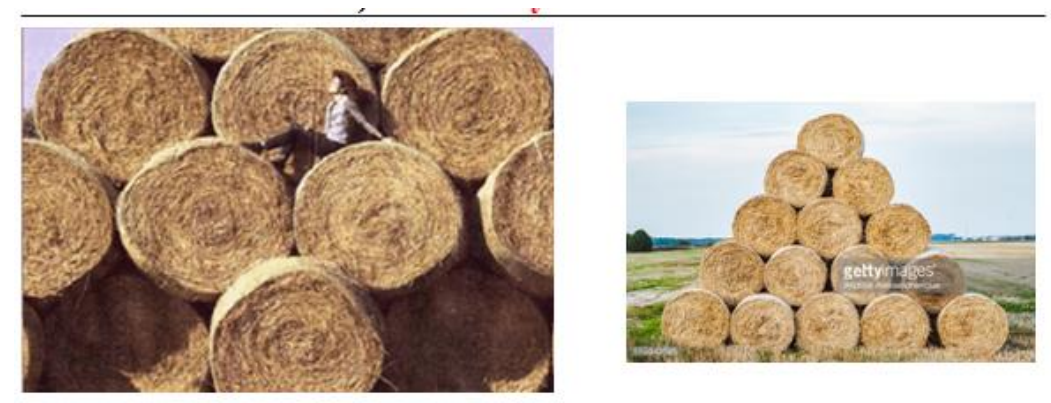

Yukarıdaki şekilde en alt sırada 5 saman balyası bulunmaktadır. Bir üst sıraya geçildiğinde her defasinda bir saman balyası eksilmektedir. En üstte bir saman balyası kaldığına göre tüm yığının yüksekliği ne kadardır? En iyi tahmininizi yapınız ve neden o sayıyı tahmin ettiğinizi matematiksel işlemlerle açılayıp düşüncelerinizi nedenleriyle ayrnnt1l yazmiz.

Şekil 3. Saman Balyası Problemi (Borromeo Ferri, 2007)

Okulunuzda yaklaşık kaç öğrenci vardır? En iyi tahmininizi yapmız ve neden o sayıyı tahmin ettiğinizi matematiksel işlemlerle açıklayıp düşüncelerinizi nedenleriyle ayrintil yazmiz.

Şekil 4. Okul Mevcudu Problemi

Suyu hangi durumlarda kullandığıızı düşünün. Sizce bir haftada ortalama ne kadar (kaç litre) su tüketiyorsunuz? En iyi tahmininizi yapınız ve neden o sayıy1 tahmin ettiğinizi matematiksel işlemlerle açıklayıp düşüncelerinizi nedenleriyle ayrintili yazmiz.

Şekil 5. Su Harcama Problemi (LEMA, 2009)

Okul binanızın önündeki bahçeye en fazla kaç araç park edebilir? Araçları bahçeye nasıl yerleştirirsiniz? Çözümünüzü matematiksel işlemlerle ayrıntilı olarak açıklayıp düşüncelerinizi nedenleriyle ayrıntilı yazınız.

Şekil 6. Otopark Problemi (LEMA, 2009)

\section{Veri Toplama Süreci}

Araştırmanın veri toplama süreci aşağıda belirtildiği gibi ilerlemiştir:

1) Okulların belirlenmesi süreci: İlk olarak il geneli yapılan sınavlar dikkate alınarak bu sınavlarda ortalama başarıya sahip ortaokullar belirlenmiştir. Bu ortaokullar arasından yönetici ve öğretmen isteklilikleri doğrultusunda araştırma kapsamında üç ortaokul seçilmiştir. Aynı zamanda, uygulama yapılacak ortaokullarda daha önce bir proje, çalıştay benzeri çalışmalar kapsamında öğrencilere modelleme uygulaması yapılmamış olmasına dikkat edilmiştir. Bu sayede öğrencilerin bu süreçteki genel düzeyleri ve yaklaşımları açığa çıkarılmaya çalışılmıştır.

2) Şubelerin belirlenmesi süreci: Öğretmenlerle iletişime geçilerek ve öğrencilerin uygulamaya ilişkin istekliliklerini dikkate alarak onlardan okul başarısını yansıtacak ortalama bir şube seçmeleri istenmiştir. Bu doğrultuda üç şube ve toplam 64 öğrenci seçilmiştir.

3) Uygulama süreci: Üç farklı ortaokulda seçilen birer şubenin matematik derslerinde öğretmenlerinin rehberliğinde, öğrencilerden dört matematiksel modelleme problemini Carlson Larsen ve Lesh'in (2003) önerdiği gibi süre sinırlaması olmadan bireysel olarak çözmeleri istenmiştir. Çözüm sırasında iki gözlemci gözlem notları almış ve çözüm sonunda öğrencilerin yazılı yanıt kağıtları toplanarak gözlem notları ile birlikte veri analizine tabi tutulmuştur.

Veri toplama süreci sonunda elde edilen 64 sayfalık yazılı yanıt kağıtları ve iki araştırmacı tarafından ayrı ayrı olarak çözüm sürecinde alınan toplamda 17 sayfalık gözlem notları araştırmanın verilerini oluşturmuştur.

\section{Verilerin Analizi}


Araştırmada verilerin analizinde içerik analizi yönteminden yararlanılmıştır. Bu sayede karmaşık modelleme sürecinde ortaya çıkan yaklaşımlara ilişkin daha derin açılamalar getirebilmek amaçlanmıștır. Araştırmanın veri analizi sürecinde izlenilen yol aşağıda verilmiştir.

1) Verilerin kodlanmasi

2) Geçici kategorilerin belirlenmesi

3) Kodların kategorilere uygun hale getirilmesi

4) Geçici kategorilerin kesin hale getirilmesi

5) Kategorilerin genel özeliklerinin belirlenmesi

6) Kategorilerin arasındaki farklılıkların belirlenmesi

7) Araştırmanın amacı ve elde edilen kod ve kategoriler doğrultusunda bulguların organize edilmesi

Strauss ve Corbin'in (1990) ifade ettiği üç farklı kodlama türünden kuramsal çerçeveye bağlı kodlama süreci dikkate alınmıştır. Bu doğrultuda araştırmada, Hıdıroğlu'nun (2015) matematiksel modelleme sürecinin temel bileşenleri, temel basamakları ve özellikleri, Diezmann ve English (2001), Elia ve diğerleri (2007), Neria ve Amit (2004), Preston ve Garner'ın (2003) açıkladıkları farklı temsil türleri dikkate alınarak gerekli kodlamalar ve kategorilendirmeler yapılmıștır.

Verilerin analizi sürecinde, kodlayıcılar arası güvenirlik formülü (Miles ve Huberman, 1994) kullanılmıș ve iki kodlayıcı arasındaki güvenirlik \% 92 olarak hesaplanmıştır. Miles ve Huberman (1994), iyi bir nitel güvenirlik için kodlamanın güvenirliğinin en az \% 80 uyum düzeyinde olması gerektiğini vurgulamaktadır. Çalışmada kodlayıcılar arası güvenirliğin yüksek çıktığı görülmüştür. Araştırmanın bulguları sunulurken modelleme sürecini açıklayan temel kavramlar verilerle ayrıntılı bir şekilde desteklenerek açıklanmıştır (Patton, 2002). Güvenirlik için veri toplamada çeşitleme, eş değerlendirme ve denetleme stratejileri (Merriam, 2013) dikkate alınmış ve araştırmanın süreci ayrıntılı bir şekilde açıklanmıştır (Charmaz, 2006).

\section{BULGULAR}

Bulgular üç alt problem dikkate alınarak üç farklı bölümde ele alınmıştır. Bu doğrultuda, ilk olarak altıncı sınıf öğrencilerinin gerçek yaşam problem durumu modellerinin yapısını etkileyen faktörler, ikinci bölümde oluşturdukları bu modellerin türleri ve son bölümde öğrencilerin bu modelleri sürecin ileriki basamaklarında nasıl kullandıkları açıklanmıştır.

Verilerin analizi doğrultusunda, gerçek yaşam problem durumu modelinin yapısını etkileyen faktörler; problem kaynaklı ve öğrenci kaynaklı olmak üzere iki grupta toplanmıștır. Problem kaynaklı faktör problemin içeriği ile ilgiliyken, öğrenci kaynaklı faktörler problemi anlama, gerçek yaşam deneyimleri, tahmin/ölçümler ve matematiksel önbilgi olmuştur. Öğrencilerin çözümdeki gerçek yaşam problem durumu modelleri resim, şekil ve tablo/liste olmak üzere üç farklı türde ortaya çıkmıştır. Son olarak da öğrencilerin oluşturdukları gerçek yaşam problem durumu modellerini matematiksel çözüme ulaşma, matematiksel sonuçlara ulaşma ve yorumlama olmak üzere üç farklı şekilde çözümde kullandıkları belirlenmiştir (bkz. Tablo 1). Tabloda, ilgili kategorilerin 264 farklı çözümdeki karşılaşılma durumları, problemlerin türleri dikkate alınarak frekansları ve yüzdeleriyle birlikte verilmiştir. Kod ve kategorilerin karşılaşma sıklıklarını veren Tablo 1'deki değerler, bulgularda ilgili bölümlere ilişkin açıklamalar yapılırken gerekli görüldüğünde yorumlanmıștır. 
Tablo 1. Veri analizinden elde edilen kod ve kategorilere ilişkin bazı bilgiler

\begin{tabular}{|c|c|c|c|c|c|c|c|c|}
\hline \multirow{2}{*}{ KATEGORILIER } & & \multirow{2}{*}{ PROBLEMLER } & \multicolumn{4}{|c|}{ MODELLEME PROBLEMLERİ } & \multirow{2}{*}{$\begin{array}{c}\text { Toplam } \\
\text { Frekans } \\
T(n) \\
\end{array}$} & \multirow{2}{*}{$\begin{array}{l}\text { Yüzde } \\
(\%)\end{array}$} \\
\hline & & & $\begin{array}{l}\text { Saman } \\
\text { Balyast } \\
\end{array}$ & $\begin{array}{c}\text { Okul } \\
\text { Mevcudu }\end{array}$ & $\begin{array}{c}\mathrm{Su} \\
\text { Harcama } \\
\end{array}$ & Otopark & & \\
\hline \multirow{5}{*}{$\begin{array}{l}\text { Gerçek Yaşam } \\
\text { Durumu } \\
\text { Modelinin } \\
\text { Yapısını } \\
\text { Etkileyen } \\
\text { Faktörler }\end{array}$} & $\begin{array}{l}\text { Problem } \\
\text { Kaynaklı } \\
\end{array}$ & 1) Problemin İçeriği & - & - & - & - & - & - \\
\hline & \multirow{4}{*}{$\begin{array}{l}\text { Öğrenci } \\
\text { Kaynaklı }\end{array}$} & 1) Problemi Anlama & 27 & 47 & 46 & 41 & 161 & 63 \\
\hline & & $\begin{array}{l}\text { 2) Gerçek Yaşam } \\
\text { Deneyimleri }\end{array}$ & 11 & 44 & 49 & 30 & 134 & 52 \\
\hline & & 3)Tahmin/Ölçümler & 20 & 47 & 47 & 38 & 152 & 59 \\
\hline & & $\begin{array}{l}\text { 4)Matematiksel } \\
\text { Önbilgi }\end{array}$ & 30 & 44 & 43 & 26 & 143 & 56 \\
\hline \multirow{3}{*}{\multicolumn{2}{|c|}{$\begin{array}{l}\text { Gerçek Yaşam Problem } \\
\text { Durumu Modelinin Türü }\end{array}$}} & 1) Resim & 24 & 0 & 3 & 19 & 46 & 18 \\
\hline & & 2) Şekil & 12 & 0 & 0 & 17 & 29 & 11 \\
\hline & & 3) Tablo/Liste & 5 & 47 & 46 & 5 & 103 & 40 \\
\hline \multirow{3}{*}{\multicolumn{2}{|c|}{$\begin{array}{l}\text { Gerçek Yaşam Problem } \\
\text { Durumu Modelinin } \\
\text { Modelleme Sürecinde } \\
\text { Kullanımı }\end{array}$}} & $\begin{array}{l}\text { 1) Matematiksel } \\
\text { Çözüme Ulașma }\end{array}$ & 18 & 16 & 15 & 23 & 72 & 28 \\
\hline & & $\begin{array}{l}\text { 2) Matematiksel } \\
\text { Sonuçlara Ulaşma }\end{array}$ & 2 & 9 & 5 & 2 & 18 & 7 \\
\hline & & 3) Yorumlama & 9 & 11 & 7 & 12 & 39 & 15 \\
\hline
\end{tabular}

\section{Gerçek Yaşam Problem Durumu Modelinin Yapısını Etkileyen Faktörler}

\section{Problem Kaynaklı}

\section{Problemin İçeriği}

Öğrencilerin çözümlerinde oluşturdukları gerçek yaşam problem durumu modelini etkileyen problem kaynaklı faktörlerden biri problemin içeriğidir. Modellemede, öğrenciler problemin içeriği doğrultusunda istenilenleri ve verilenleri belirleyerek çözüm için en uygun olduğunu düşündükleri gerçek yaşam problem durumu modelini oluşturmuşlardır. Farklı problemlere ilişskin aynı öğrencinin ve aynı probleme ilişkin farklı öğrencilerin çözümleri incelendiğinde, öğrencilerin oluşturdukları gerçek yaşam problem durumu modelleri problemin içeriğine göre farklılıklar göstermiştir. Tablo 1 incelendiğinde, Saman Balyası (24 resim + 12 șekil) ve Otopark (19 resim + 17 şekil) Problemleri'nde öğrencilerin gerçek yaşam problem durumu modellerinin türlerinin resim ve şekil olduğu ve Saman Balyası ve Otopark Problemi'nde sadece beșer öğrencinin tablo/liste türünde modeller oluşturduğu belirlenmiştir. Bunun aksine, Okul Mevcudu (47 tablo/liste) ve Su Harcama (46 tablo/liste) Problemleri'nde öğrencilerin modelleri genellikle tablo/liste türünde olmuştur. Okul Mevcudu ve Su Harcama Problemleri'ne ilişkin çözümlerde tablo/liste türünden farklı olarak sadece üç tane resim içeren çözümle karşılaşılmıştır. Bu durum, problem içeriğinin öğrencilerin oluşturdukları modellerin yapısında önemli bir etken olduğunu göstermiștir.

\section{Öğrenci Kaynaklı}

Öğrencilerin çözümleri incelendiğinde, oluşturdukları gerçek yaşam problem durumu modelleri öğrenciden kaynaklı dört faktörden etkilenmiştir. Bunlar; öğrencilerin problemi anlama durumları, gerçek yaşam deneyimleri, tahmin/ölçümleri ve matematiksel önbilgileridir.

\section{Problemi Anlama}

Öğrencilerin modelleme problemlerini anlamamaları gerçek yaşam problem durumu modellerini etkileyen öğrenci faktörlerinden biri olmuştur. Tablo 1 incelendiğinde, öğrencilerin toplamda 256 çözümünün \%37'sinde (95 çözüm) problemi anlayamadıkları belirlenmiştir. Bu oldukça yüksek bir oran olduğu gibi etkili modellerin oluşturulmasını engelleyen en temel unsurdur; çünkü problemi anlama modelleme sürecinin ilk basamağını temsil eder. Özellikle Saman Balyası Problemi'nde (\%58 - problemi anlamama) öğrenciler verilenleri ve istenenleri anlayamamışlar ve istenilen çözüm sürecine başlayamamışlardır. Problemi anlayamayan bu öğrenciler, çözümde de ya gerçek yaşam problem durumu modelini oluşturamamışlar ya da çözüm için oldukça alakasız resim 
türünde modellere yer vermişlerdir. Örneğin Ö$_{4}$ 'ün Saman Balyası Problemi'ne ilişkin çözümüne bakıldığında, $\ddot{O}_{4}$ problemde istenileni anlamamış ve bu nedenle çözümle alakasız açıklamalarda bulunmuştur. Problemde yüksekliği birim (metre, santimetre gibi) cinsinden gerekçelendirerek tahmin etmesi beklenirken, kendisi çözümünde resimde verilen saman balyalarının şeklinin nasıl olduğuna ilişkin ifadelere yer vermiştir (bkz. Şekil 7).

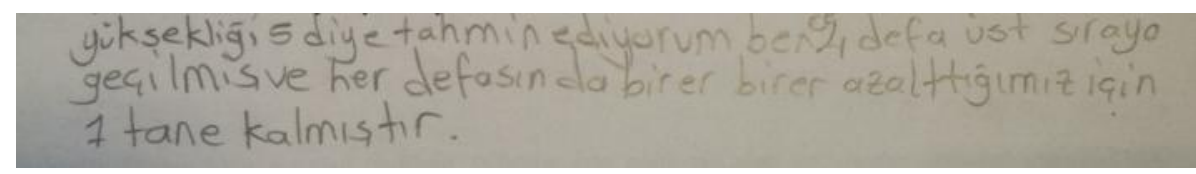

Şekil 7. $\ddot{O}_{4}$ ün Saman Balyası Problemi'ne ilişskin çözümü

Ö ${ }_{14}^{\prime}$ ün Saman Balyası Problemi'ne ilişkin çözümüne bakıldığında, Ö ${ }_{14}$ problemle birlikte verilen resmi yanlış yorumlamış ve problemde verilenleri anlayamamıştır. Onun çözümüne göre, her sırada beş balya ve yukarı doğru beş sıra bulunmaktadır. Buradan hareketle 5 ile 5’i çarpmıştır. Ö ${ }_{14}$, resimdeki balya sayısını yanlış hesapladığı gibi bulduğu matematiksel çözümü de metre olarak ifade etmiştir. Ö$_{14}$, problemi anlayamadığı için problemde istenileni ve verilenleri ortaya koyamamış ve çözümde alakasız ifadelere yer vermiştir (bkz. Şekil 8).

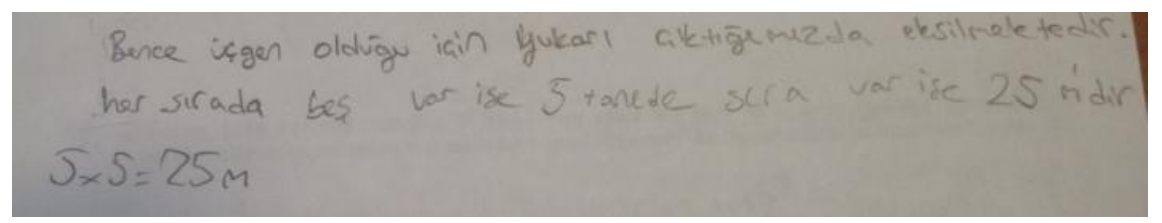

Şekil 8. Ö14'ün Saman Balyası Problemi'ne ilişkin çözümü

Gözlem notları da öğrencilerin bazılarının problemleri anlayamadıklarını ve özellikle problemde istenilenleri ve verilenleri ortaya çıkaramadıklarını göstermiştir:

"Öğrencilerin bazıları problemde istenilen şeyin ne olduğunu ortaya çıkaramadı. Bazısı Saman Balyası Problemi'ni okuduktan sonra öğretmenlerine hemen "15 tane saman balyası var." "Çok kolaymıs.." gibi ifadeler kullandı." (Gözlem Notu B: A Ortaokulu)

" $\ddot{O}_{22}$ Otopark Problemi'ni çözerken bahçedeki araba sayısının kaç tane olduğunun problemde istenildiğini ifade etti ve pencereye arabaları saymaya yöneldi." (Gözlem Notu A: C Ortaokulu)

Ö$_{19}$ 'un Okul Mevcudu Problemi'ne ilişkin çözümü incelendiğinde, onun da problemi anlamadığı, istenilenleri ve verilenleri açığa çıkaramadığı görülmüştür(bkz. Şekil 9).

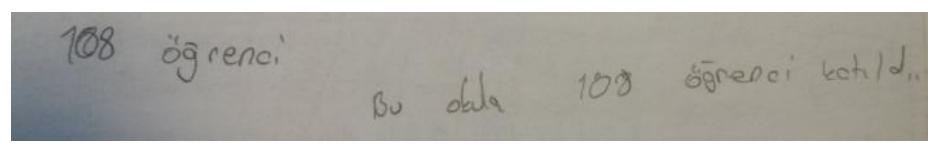

Şekil 9. Ö19'un Okul Mevcudu Problemi'ne ilişkin çözümü

Problemde kendisinden okulun mevcut öğrenci sayısını tahmin etmesi beklendiği halde çözümdeki "Bu okula 108 öğrenci katıldı." ifadesi onun problemi anlamada sıkıntı yaşadığını göstermiştir.

\section{Gerçek Yaşam Deneyimleri}

Öğrencilerin gerçek yaşam problem durumuna ilişkin deneyimleri onların çözümde gerçekçi bir problem durumu modeli oluşturmalarına firsat sağlayan önemli etkenlerden biri olmuştur. Öğrencilerin çözümleri incelendiğinde, Saman Balyası Problemi düzeylerine göre çok zor olmadığı halde onların bu probleme ilişkin gerçek yaşam deneyimlerinin olmaması bu problemin çözümünde başarısız olmalarındaki önemli bir etkendir. Farklı olarak öğrenciler, gerçek yaşam deneyimlerinin fazla olduğu Sınıf Mevcudu Problemi'nde diğer problemlere göre çok daha başarılı olmuşlardır (bkz. 
Tablo 1). Var olan gerçek yaşam problem durumu deneyimleri stratejik etkenleri ortaya çıkarmalarında ve gerçek yaşam ilişkilerini daha rahat kurabilmelerinde onlara firsat sağlamıştır.

“Öğrenciler özellikle kendi yaşamlarında anlamlandırdıkları problemlerin çözümüne öncelik veriyorlar. ... Ö ${ }_{34}$ Sinıf Mevcudu Problemi'ne daha fazla zaman ayırdı.... Ö ${ }_{34}$, Sinıf Mevcudu Problemi'ne ilişkin daha fazla gerçek yaşam bilgisi ortaya koydu. $\ddot{O}_{28}$ de Su Harcama Problemi'ne daha fazla vakit ayırarak deneyimlerini çözüme yansıtmaya çalıştı." (Gözlem Notu B: B Ortaokulu)

"Ö 52 Otopark Problemi'ni sevdiğini ifade etti. Arabaların uzunlukları ile ilgili kendi arabalarını düşünerek bazı deneyimlerini açığa çıkardı.” (Gözlem Notu A: A Ortaokulu)

$\ddot{O}_{14}$ Okul Mevcudu Problemi'ne ilişkin çözümünde, mevcut problem ile ilgili gerçek yaşam deneyimlerine sahip olduğu halde bunlardan yararlanmadan gerekçesiz ve gerçekçi olmayan tahminlerde bulunarak bir çözüme ulașmıștır. Ö ${ }_{14}^{\prime}$ ün sınıfının mevcudu 23 olmasına rağmen kendi sınıfını dikkate almadan çözüme ilişkin bir tahminde bulunduğu görülmüştür. Bu problemde öğrencilerin kendi sınıf ortamlarından yararlanarak oluşturdukları gerçek yaşam problem durumu modelleri daha gerçekçi çözümlere fırsat sağlamıștır. Diğer problemlere kıyasla bu problemde daha başarılı olmalarının nedeninin deneyimlerine daha çok yer verebilecekleri bir çözüm sürecinin açığa çıkmasından kaynaklandığı söylenebilir (bkz. Şekil 10).

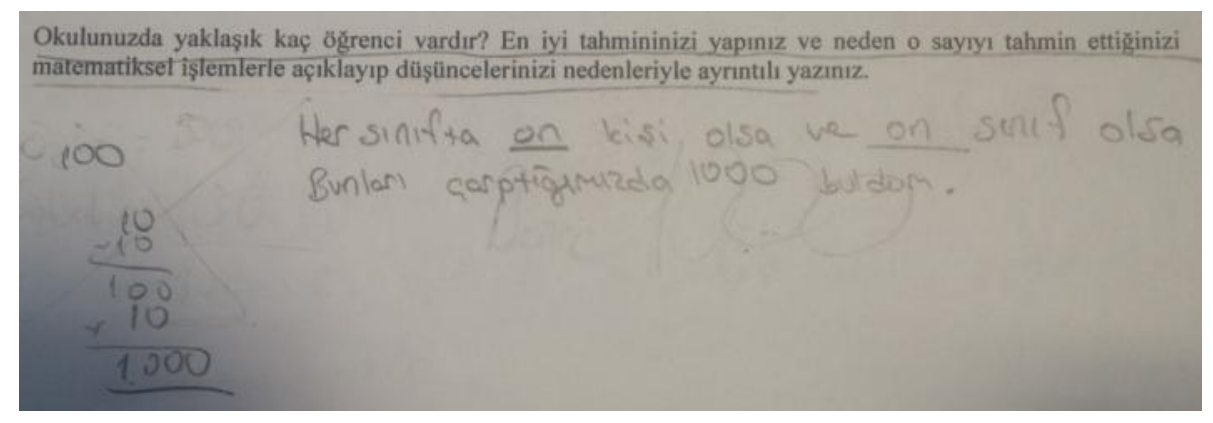

Şekil 10. Ö14'ün Okul Mevcudu Problemi'ne ilişkin çözümü

Bazı öğrenciler Otopark Problemi'nde arabalar arasındaki mesafeyi dikkate almadan işlemlerini sürdürmüşler veya gerçek yaşam problem durumu modellerinde boşluklara hiç yer vermemişlerdir. Modellerinde boşluklara yer vermemeleri gerçek yaşam deneyimlerini çözüme iyi bir şekilde yansıtamadıklarının kanıtı olabilir. Halbuki öğrenciler çözerlerken arabaların arasındaki boşluklardan bahsetmişlerdir. Örneğin Ö$_{28}$, gerçek yaşam deneyimlerini modeline yansıtmamış ve okulun önündeki bahçeye park edecek araçların arasındaki boşlukları dikkate almadan çözümünü sürdürmüştür (bkz. Şekil 11).

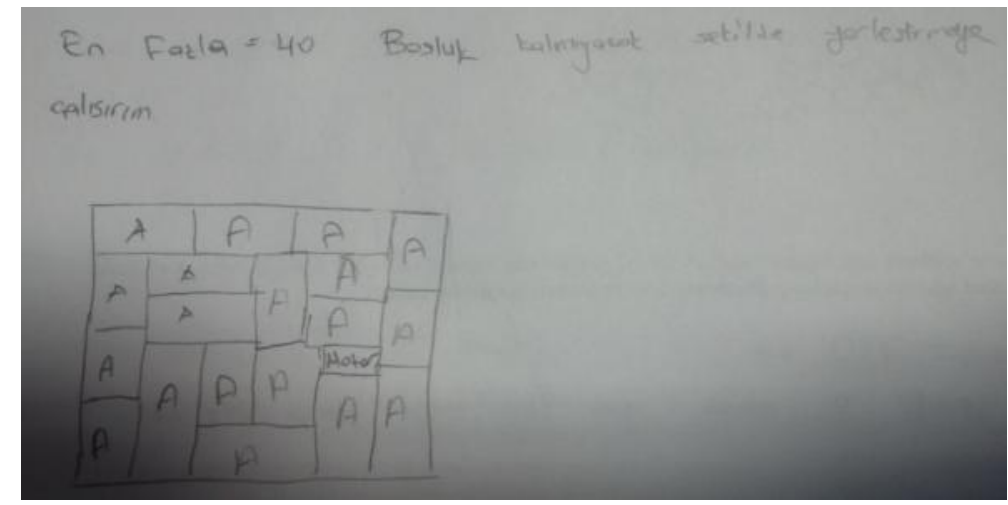

Şekil 11. $\ddot{O}_{28}$ 'in Otopark Problemi'ne ilişkin çözümü

“Ö${ }_{28}$ arabaların arasında mesafenin olması gerektiğini ve hep araba olmayabileceğini ifade etti. .....̈̈ 28 ve $\ddot{O}_{34}$ söyledikleri halde çözümde boşlukları dikkate almıyorlar." (Gözlem Notu A: B Ortaokulu) 
Bazı öğrenciler de gerçek yaşam problem durumu modellerinde araçlar arasındaki boşluklara yer verdikleri halde çözümlerine bu boşlukların etkilerini yansıtmamışlardır. Bu durum, çözümdeki ileriki aşamalarda gerçek yaşam deneyimlerinin gerçek modelden transfer edilemediğini ve modellerin resim (ikinci bölümde ayrıntılı ele alınmıştır) türünde kaldığını göstermiştir. Örneğin Ö ${ }_{51}$, modelinde araçlar arasındaki boşlukları resmetse de çözüm için gerekliliği ortaya çıkaramayarak çözümünü gerekçelendirmeden sonlandırmıştır (bkz. Şekil 12).

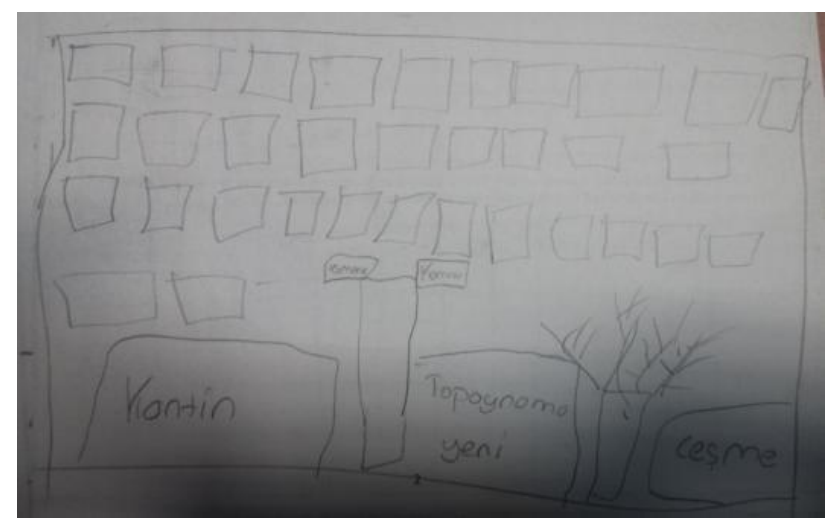

Şekil 12. Ö ${ }_{51}$ 'in Otopark Problemi'ne ilişskin çözümü

Ö$_{44}$ 'ün Okul Mevcudu Problemi'ne ilişkin çözümü incelendiğinde, Ö ${ }_{44}$ gerçek yaşam problem durumu modelini tablo/liste türünde oluşturmuştur. Ö $_{44}$, kendi sınıfından hareketle her sinıfın 25 kişiden oluşacağı varsayımında bulunarak, toplam sınıf sayısını ve ana sınıfı, sabahçı/öğlenci ayrımını dikkate alarak çözümünü tamamlanmıştır. Ö ${ }_{44}$ kardeşinin ana sınıfında olduğunu ifade etmiş ve onun sınıfının kendi sınıfından daha az mevcuda sahip olduğunu belirtmiştir (bkz. Şekil 13).

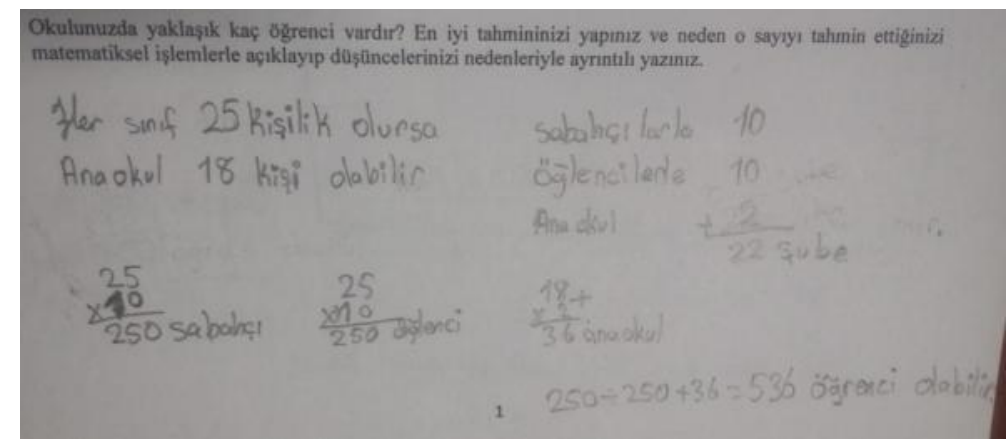

Şekil 13. Ö44'ün Okul Mevcudu Problemi'ne ilişkin çözümü

İlgili durumu açlklayan gözlem notu aşağıda verilmiştir. Görüldüğü gibi, Ö 44 'ün gerçek yaşam deneyimleri hem gerçek yaşam problem durumu modellerini şekillendirmiş hem de model için kullanabilecekleri bazı tahminlerin etkililiğini artmıştır.

“Ö 44 Sınıflarının 25 kişi olduğunu söyledi. $\ddot{4}_{44}$ okuldaki sınıfları yazarken ana sınıflarını da almasının gerektiğini ifade etti. ...Ö̈44 kardeşinin ana sınıfında olduğunu söyledi. ... Kardeşinin sınıfının onların sınıfından daha az olduğunu söyleyerek 18 olarak ifade etti." (Gözlem Notu A: B Ortaokulu)

Öğrencilerden bazıları geçici olarak, gerçek yaşamda kısıtlı durumlarda var olan şartları, çözümlerinde genel bir durum gibi düşünmüşlerdir. Su Harcama Problemi çözümünde bazıları genel durumu düşünmeden sadece oruçlu oldukları zamanı çözümde dikkate almıştır. Örneğin, Ö $50 \mathrm{Su}$ Harcama Problemi'nde sadece o anki şartları dikkate alarak çözümünü yapmıştır (bkz. Şekil 14).

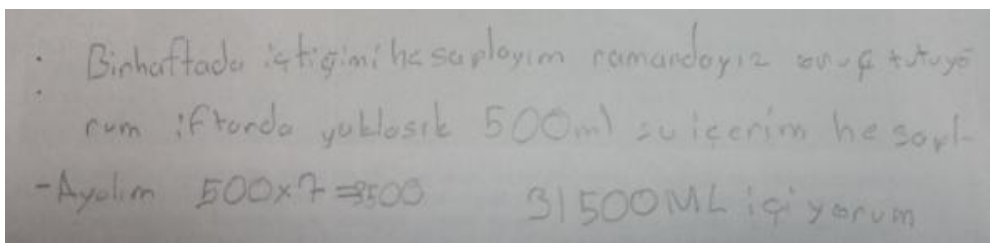


Şekil 14. Ö5o'nin Su Harcama Problemi'ne ilişkin çözümü

Bazıları ise hem normal hem de oruçlu iken ayrı ayrı şartları ele alarak çözümde tablo/liste şeklinde gerçek modellerini oluşturarak çözümlerini sürdürmüşlerdir (bkz. Şekil 15).

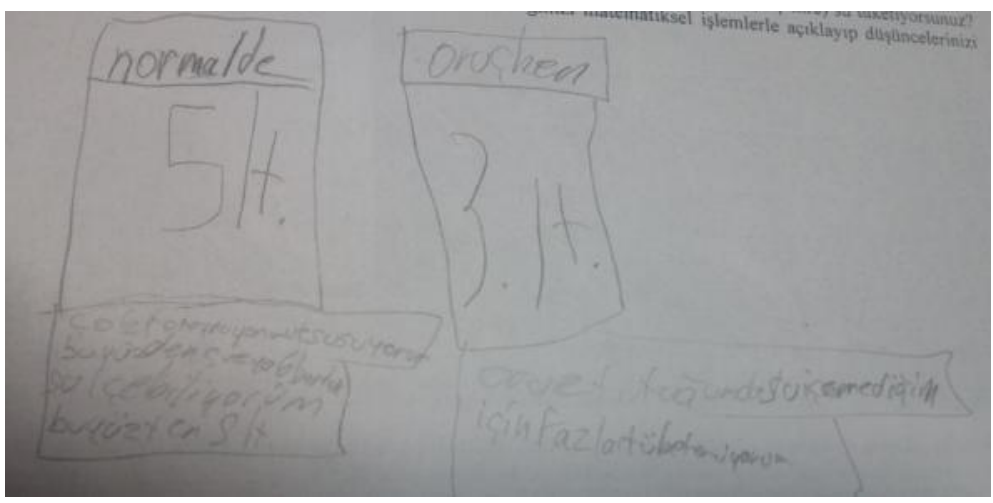

Şekil 15. Ö ${ }_{53}$ ün Su Harcama Problemi'ne ilişkin çözümü

Buradan öğrencilerin gerçek yaşam deneyimlerinin onların modellerini ve çözüm yollarını etkilediği görülmüștür. Ö${ }_{53}$ ise, hem o anki hem de genel şartları dikkate alarak daha nitelikli bir gerçek model oluşturmuştur (bkz. Şekil 15).

\section{Tahmin/Ölçümler}

Öğrencilerin gerçek yașam problem durumu modellerini etkileyen öğrenci kaynaklı unsurlardan bir diğeri çözümlerinde yapmıș oldukları tahmin/ölçümlerdir. Ö̈'in Otopark Problemi'ne ilișkin çözümü incelendiğinde, $\ddot{O}_{11}$ gerçek bir model oluşturmuș, aynı zamanda araba boyutu ve bahçe boyutunu tahminlerine bağlı olarak oranlamış ve araçlar arasındaki boşlukları modelde ifade etmiştir (bkz. Şekil 16). Fakat bunları çözümünde gerekçelendirmemiştir. Bunun yanı sıra, çizilen şekil gerçek yaşam için ideal değildir ve çizimlerinde gerekçelendirme olmayan tahminlerden yararlanılmıştır.

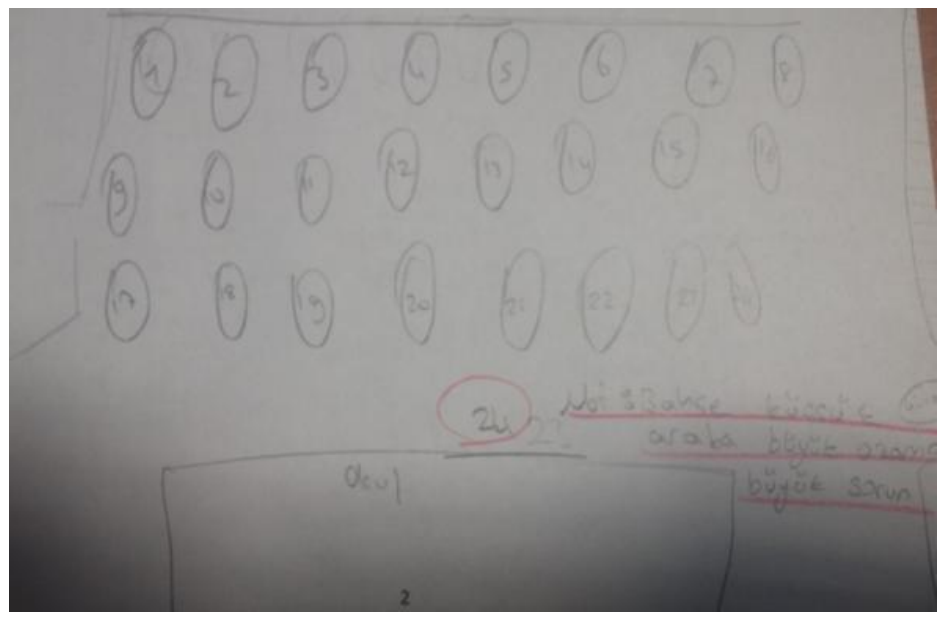

Șekil 16. Ö11'in Otopark Problemi'ne ilișkin çözümü

$\ddot{O}_{35}$ 'in Otopark Problemi'ne ilişkin çözümü incelendiğinde, gerçek yaşam problem durumu modeli gerekçelendirilmemiş tahminlerle meydana gelmiştir ve bu nedenle gerçek modelin türü çözümde resim düzeyinde kalmıştır (bkz. Şekil 17). 


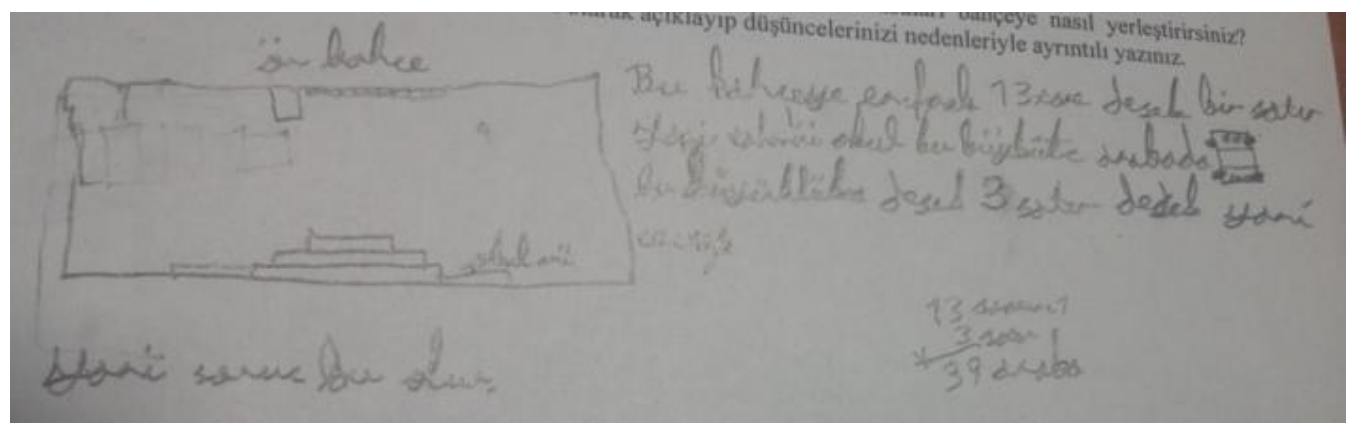

Şekil 17. $\ddot{O}_{35}$ 'in Otopark Problemi'ne ilişsin çözümü

Özellikle problemi anlamayan öğrencilerin çözümlerinde, gerekçelendirilmemiş tahminlere sık sık başvurdukları ve nitelikli gerçek modeller oluşturmadıkları için çözümde başarısız oldukları görülmüştür. Öğrenciler bu tür durumlarda "Bence 150" "Bana göre 100 tane araba alır" gibi ifadelerle çözümünü sonlandırmışlardır.

\section{Matematiksel Önbilgi}

Gerçek yaşam problem durumu modelleri, problem çözüm sürecinde gerçek yaşamdan matematiğe geçişte bir köprü olurken bu modellerin oluşumunda öğrencilerin matematiksel önbilgileri önemli olmuştur. Örneğin, öğrenciler çözüm sürecinde gerçek yaşam problem durumu modellerini, problemi matematiksel olarak çözebilecekleri hale getirmişlerdir. Öğrenciler sahip oldukları matematiksel önbilgilere göre, stratejik etkenleri görmezden gelme veya varsayımları değiştirme olarak farklı yaklaşımlarda bulunarak daha az karmaşık modellerle çözüme ulaşmaya çalışmışlardır. Modellemede bazı öğrenciler birim kavramını bilmediklerinden dolayı yanlış birimlerle modeli oluşturmuşlar ve ideal bir model elde edememişlerdir. Bu nedenle, matematiksel işlemleri doğru olsa da ideal matematiksel çözüme ulaşamamışlardır. Örneğin, Ö̈ ${ }_{49}$ un Saman Balyası Problemi'ne ilişkin çözümünde Ö$_{49}$ uzunluk ve alan birimlerini karıștırmıștır (bkz. Şekil 18).

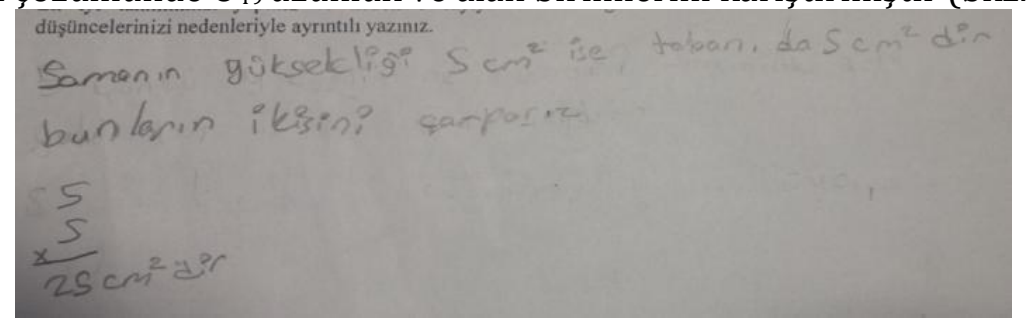

Şekil 18. Ö49'un Saman Balyası Problemi'ne ilişkin çözümü

Ö$_{52}$ 'nin Su Harcama Problemi'ne ilişkin çözümü incelendiğinde, birimler arasındaki ilişkileri kuramadığı belirlenmiştir (bkz. Şekil 19). Öğrencilerin araçları ve bahçenin şeklini dikdörtgen olarak ele almaya çalışmaları, saman balyasının ön kesitini çember olarak düşünmeleri, otoparkta araçlar arasındaki mesafeleri bilseler de modellerine bunu yansıtmamaları, tahminlerinde işlem kolaylığını sağlayacak değerleri tercih etmeleri, farklı boyutlardaki araçlar yerine daha çok aynı boyutlardaki araçları seçmeleri gibi yaklaşımlarla karşılaşılmıştır. Onların bu sınırlamalara gitmelerinde matematiksel bilgilerinin eksik oluşunun ve bu şekilde çözüme ulaşamayacakları düşüncesinin etkili olduğu söylenebilir. 


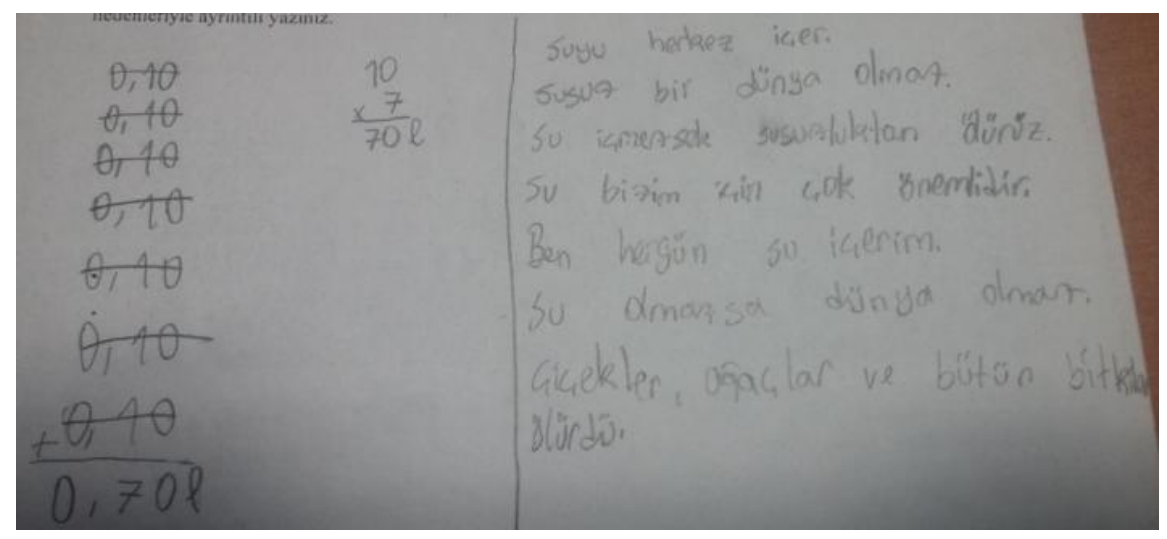

Şekil 19. Ö ${ }_{52}$ nin Su Harcama Problemi'ne ilişkin çözümü

“ $\ddot{O}_{52}$ her gün 0.10 litre su içtiğini ifade etti. ... 1 haftada 0.70 litre içtiğini yazdı. ... $\ddot{O}_{52} \mathrm{Su}$ Harcama Problemi'nde çözümle alakasız şeyler yazıyor... 0.70 litrenin 70 litre olduğunu ifade ederek "Bu kadar su içerim ben." dedi ve çözümü bitirdi." (Gözlem Notu A: A Ortaokulu)

\section{Gerçek Yaşam Problem Durumu Modelinin Türü}

Öğrencilerin modelleme sürecinde oluşturdukları gerçek yaşam problem durumu modellerin yapısı incelendiğinde, onların resim, şekil ve tablo/liste olmak üzere üç farklı model türünden faydalandıkları belirlenmiştir. Bu türlerin ortaya çıkmasında problem ve öğrenci kaynaklı faktörler büyük önem taşımışlardır.

\section{Resim}

Modelleme sürecinde başarısız olan öğrencilerin gerçek yaşam problem durumu modellerinin gereksiz stratejik etkenleri de içerdiği belirlenmiştir. Burada öğrenciler problemin çözümü için gerekli stratejik etkenleri belirleyememişler ve bu yüzden gereksiz etkenlere de gerçek yaşam problem durumu modellerinde yer vermişlerdir. Burada öğrenciler sadece gerçek yaşam deneyimleri doğrultusunda gerçek yaşamdaki söz konusu ortamı resmetmişlerdir. Modellerinin oluşumunda herhangi bir kısıtlama, stratejik olmayan etkenleri eleme, problemi çözebilecekleri hale getirme gibi eylemler söz konusu olmamıştır. Örneğin, Su Harcama Problemi çözümünde Ö ${ }_{19}$ oluşturduğu gerçek yaşam problem durumu modelinde gereksiz çizimlere yer vermiş ve stratejik etkenleri ortaya çıkaramamıştır (bkz. Şekil 20).

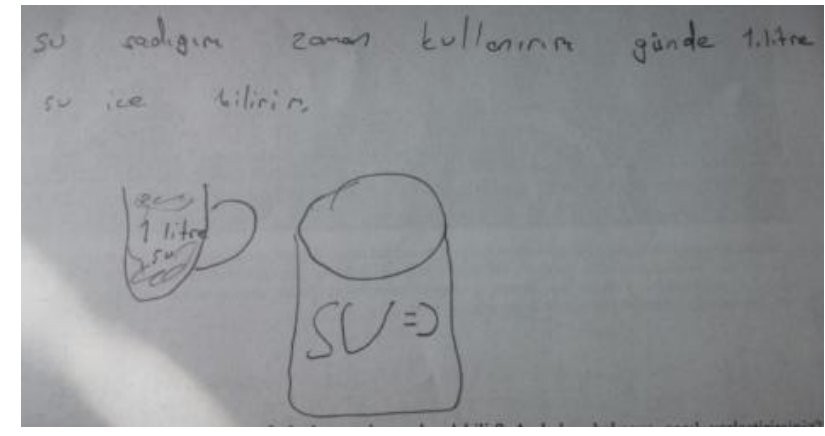

Şekil 20. Ö$_{19}$ 'un Su Harcama Problemi'ne ilişsin çözümü

$\mathrm{Bu}$ tür resimlerle öğrenciler çözüm için nitelikli gerçek yaşam problem durumu modelini oluşturamamışlar ve çözümde istenilen matematiksel çözümlere ulaşamamışlardır. Ö$_{5}$ 'in Otopark Problemi'ne ilişkin çözümünde, Ö$_{5}$ yazılı yanıt kağıdına herhangi bir gerekçelendirme yapmadan problemin gerçek modelini aktarmıştır. Çözümde model üzerinden çözümüne devam etmemiştir. Bu durum, $\mathrm{O}_{5}$ 'in modelini gerçek yaşam ile matematik arasındaki ilişkiyi kurmadan oluşturduğunu, matematikselleştirme basamağında gerçek modelini kullanamadığını ve gerçek modelin çözümde resim türünde ortaya çıktığını göstermiştir. Modelleme sürecinde gerçek yaşam problem durumu modelleri ileriki basamaklara geçmek için kullanılan bir köprü olduğundan dolayı kullanılma şekli, 
düzeyi ve öğrenci açıklamaları modelin şekil değil de, resim düzeyinde kaldığını göstermiştir. Ö sadece araba ve tır araçlarını dikkate aldığını belirtse de gerekçelendirilmemiş tahminleriyle matematiksel çözümünü sonlandırmıştır (bkz. Şekil 21).

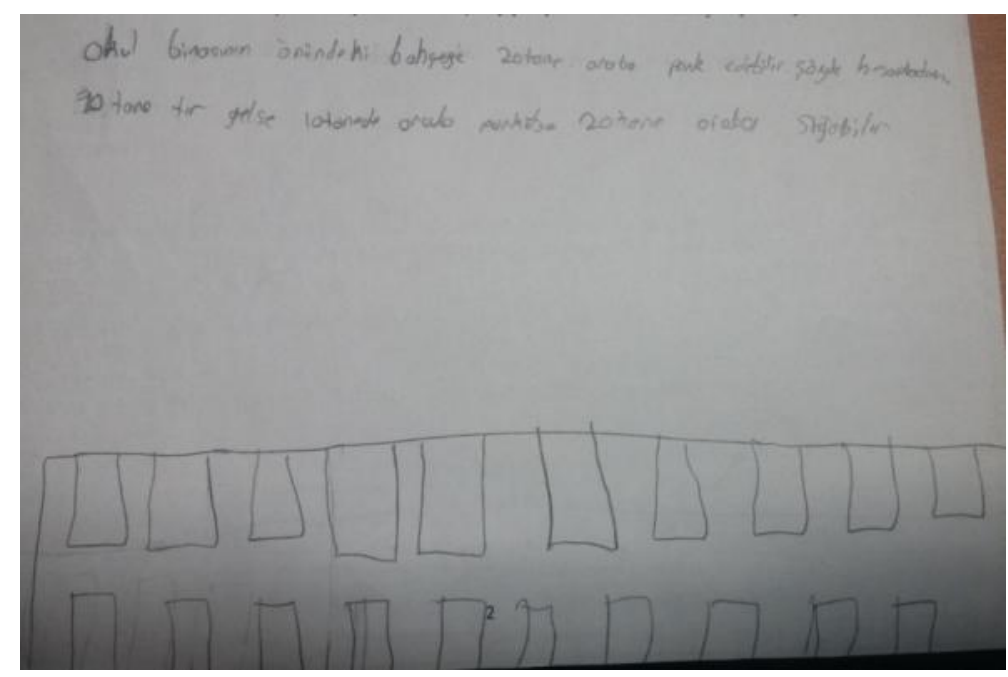

Şekil 21. Ö_'in Otopark Problemi'ne ilişkin çözümü

$\ddot{O}_{13}$ Saman Balyası Problemi'ne ilişkin çözümünde ona problemle birlikte verilmiş şeklin aynısını çözüme yansıtmaya çalışmış ve en alttaki Saman Balyası sayısını yanlış olarak çizerek hatalı bir model resmetmiştir. Ayrıca Ö$_{13}$, birimleri karıștırmış ve ileriki aşamalarda matematiksel olarak gerekli işlemleri model üzerinden yapamamıştır (bkz. Şekil 22). Bu durum, Ö ${ }_{13}^{\prime}$ ün nitelikli bir model oluşturamadığını, öğrencinin şekil düzeyinde değil, resim düzeyinde model oluşturduğunu ve bu modeli çözümde kullanamadığını göstermiştir.

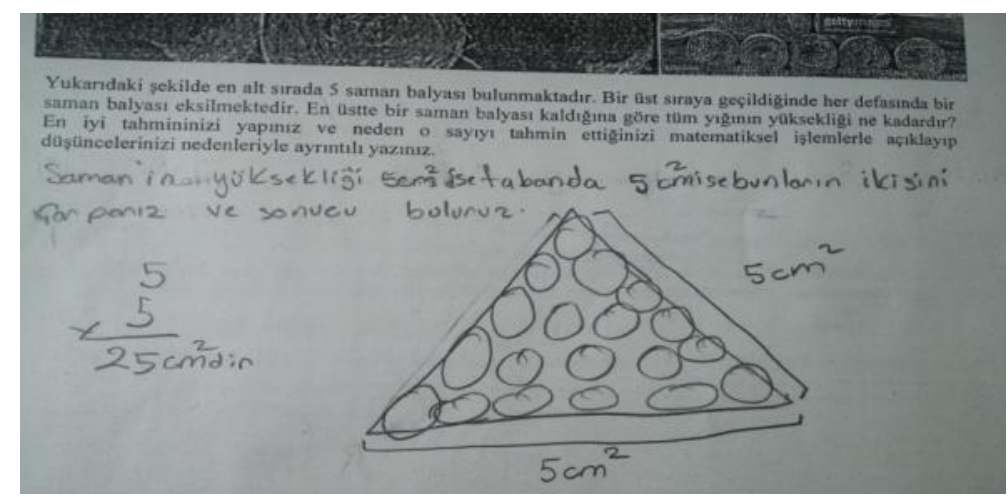

ŞEKİL 22. Ö$_{13}$ 'ün Saman Balyası Problemi'ne ilişkin çözümü

\section{Şekil}

Öğrencilerin bazıları, modellemede problem durumundaki stratejik etkenleri dikkate almış, gerçek yaşam deneyimleri ve matematiksel önbilgileri doğrultusunda gerçek yaşam durumu modellerini problemi çözebilecekleri hale getirmişlerdir. Bu şekilde modellerini oluşturan öğrenciler süreçte resim çizenlere oranla daha başarılı olmuşlardır.

$\ddot{O}_{1}$ Otopark Problemi'ne ilişkin çözümünde, stratejik etkenleri belirleyerek gerçek yaşam problem durumu modelini sadeleştirmiş, çözebileceği hale getirmiş ve stratejik etkenler olan bahçe ve araba boyutlarını ve bunların şekillerini gerçek yaşam deneyimleri, tahminleri ve matematiksel önbilgileri doğrultusunda görselleştirmiştir. Modelinde park eden araçları araba olarak genelleme, arabayı dikdörtgen șeklinde betimleme, bahçeyi dikdörtgen şeklinde belirleme gibi varsayımları ile modelini yapılandırmıştır. Modelin oluşumunda bir arabanın boyutu ve bahçe boyutları arasındaki oranı tahmin ederek gerçek yaşam problem durumu modelini şekil olarak görselleștirmiştir. Ö ${ }_{1}^{\prime}$ in araba boyutu ve bahçe boyutu arasındaki ilişki hakkındaki yaptığı tahminini çözümünde gerekçelendirmese de gözlem notları öğrencinin pencereden bakarak oranlama yaptığını 
göstermiştir (bkz. Şekil 23). Gerçek yaşam problem durumu modelinde arabalar arasındaki boşluklar da dikkate alınmıştır.

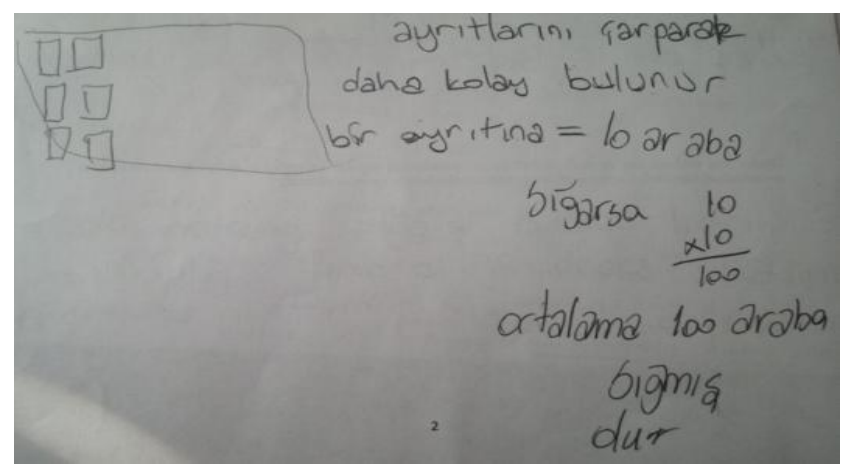

Şekil 23. Ö,'in Otopark Problemi'ne ilişkin çözümü

“Ö̈ Otopark Problemi’ni okuduktan sonra öğretmenden pencereden bahçeye bakmak için izin istedi. Diğer öğrenciler de bakmak istedi. ... Ö1 "Araba dikdörtgen gibi olur ve bahçede dikdörtgendir. Yoksa Çözemeyiz." diyerek sinırlamalara gitti. ...Ö̈ kaç tane araba sığar oranllyor." (Gözlem Notu A: C Ortaokulu)

$\ddot{O}_{2}$ Otopark Problemi'ne ilişkin çözümünde, gerekli çizimlerle araba ve bahçe boyutlarını tahminleri yardımıyla modelinde dikkate almıs ve stratejik etkenleri ayrıntılı olarak modellemeye çalışmıștır (bkz. Şekil 24). Ayrıca $\ddot{O}_{2}$, okuldaki bahçeye park edecek arabaların arasındaki mesafeyi dikkate almamış ve bahçenin konumunu tasvir etmek amacıyla kısmen gereksiz çizimlere de çözümünde yer vermiştir. Modelinin üzerinden çözümleri ve gözlem notları incelendiğinde gerekli stratejik etkenleri ayırt edebildiği belirlenmiştir.

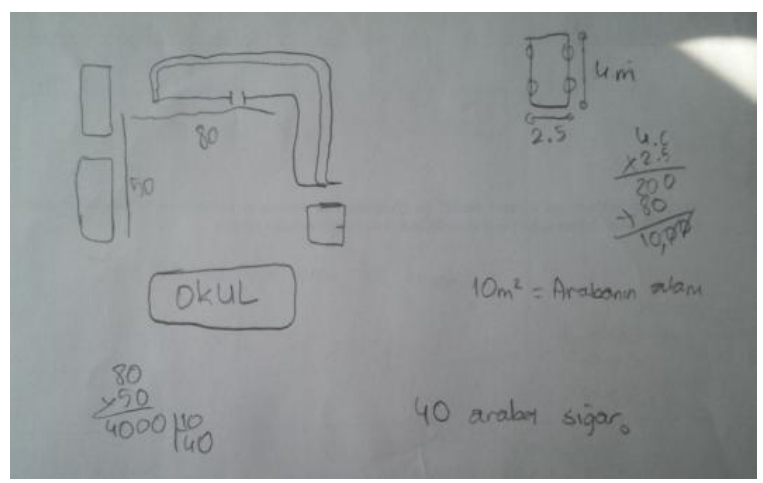

Șekil 24. Ö2'nin Otopark Problemi'ne ilișkin çözümü

“ $\ddot{O}_{2}$ "Araçlar arasındaki mesafe vardır ama çok azdır. Onu hesaba katmaya gerek yok. $O$ zaman çok zor olur dimi hocam?" diyerek öğretmeninden cevap almaya çalıştı. Öğretmeni "hangisini yapmak istiyorsan onu yapabilirsin." dedi." (Gözlem Notu B: C Ortaokulu)

Ö ${ }_{19}$ 'un Otopark Problemi'ne ilişkin çözümünde, gerçek yaşam problem durumu modeli türü şekil olarak karşımıza çıkmıştır ve sadece çözüm için gerekli stratejik etkenler modele yansıtılmıştır (bkz. Şekil 25). Bunun yanında, $\ddot{O}_{19}$; Ö$_{1}$ ve Ö${ }_{2}^{\prime}$ den farklı olarak çözümde farklı araba boyutlarını dikkate alsa da modelini gerçekçi bir șekilde çizmemiş ve modele dayanarak ulaştığı, 26 olarak bulduğu matematiksel çözümünü gerekçelendirmemiştir. Ayrıca, arabalar arasındaki boşlukları hem modelinde hem de çözümünde dikkate almamıştır. 


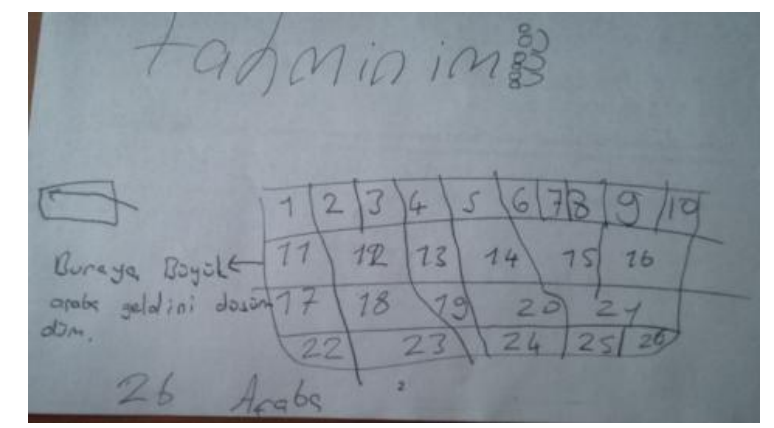

Şekil 25. Ö19'un Otopark Problemi'ne ilişskin çözümü

\section{Tablo/Liste}

Öğrencilerden bazılarının oluşturdukları gerçek yaşam problem durumu modelleri tablo/liste şeklinde ortaya çıkmıştır. Öğrenciler çözümlerinde bazen bir tablo oluşturmaktan ziyade benzer özellikleri taşıyan bir liste oluşturarak stratejik etkenleri gruplamışlar ve gerçek yaşam problem durumu modellerini elde etmişlerdir. Öğrenciler buradaki modellerinde stratejik etkenleri ayırmışlar, gruplamışlar ve etkilerini ortaya koymuşlardır. Modellerinin türünün tablo olmasında problem durumu, öğrencilerin problemdeki stratejik etkenleri doğru olarak belirlemeleri, tahminleri ve problemi matematiksel bilgileri ile çözebilecekleri ortamlar yaratmak istemeleri etkili olmuştur.

Ö$_{11}^{\prime}$ in Saman Balyası Problemi'ne ilişkin çözümünde, liste yöntemiyle oluşturmaya çalıştı̆̆ modelinde problemi anlamadığından dolayı gerekli stratejik etkenleri yanlış olarak belirlemiştir (bkz. Șekil 26). Bununla birlikte, olușturduğu liste ve yaptığı çözümle toplam saman balyası sayısını veren sayıya ulaşmıştır. Öğrencinin problemi anlamaması modeli oluşturan etkenlerin yanlış bir şekilde ele alınmasına ve modelin çözüm için işlevsiz bir halde olmasına yol açmıştır.

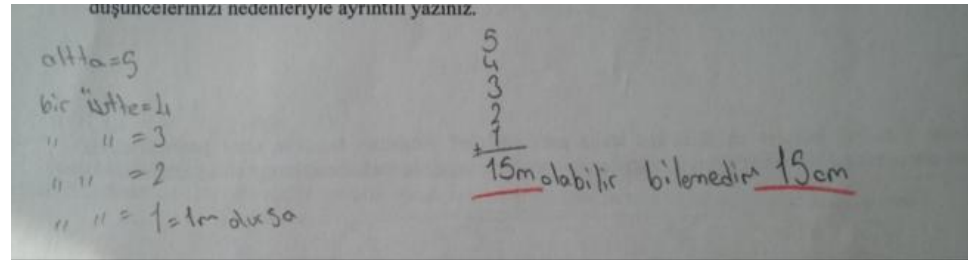

Șekil 26. $\ddot{1}_{11}$ in Saman Balyası Problemi'ne ilișkin çözümü

Ö$_{3}{ }^{\prime}$ ün Sınıf Mevcudu Problemi'ne ilişkin çözümünde, ${ }_{3}$ gerçek yaşam deneyimlerinden ve matematiksel bilgilerinden yararlanarak gerçek yaşam problem durumu modelini liste şeklinde görselleștirmiştir (bkz. Şekil 27).

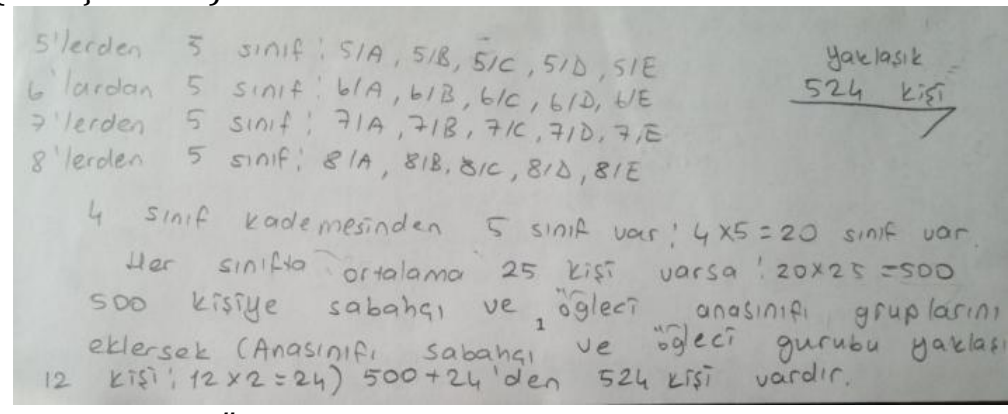

Şekil 27. Öз'ün Sinıf Mevcudu Problemi'ne ilişkin çözümü

Çözümünün devamında, her sınıfta yaklaşık olarak 25 öğrenci olacağı tahmininden hareketle matematiksel çözüme (524 öğrenci) ve farklı matematiksel sonuçlara (5-6-7-8'lerde 500 ve anasınıflarında 24 kişi olması) olarak ulaşmıştır. Ayrıca, matematiksel çözüm ve sonuçlarının gerçek yaşam durumunda ne anlama geldiğini basit yorumlarla açıklamıştır.

$\ddot{O}_{11}$ Su Harcama Problemi'ne ilişkin çözümünde, resim ve liste türünde gerçek modellere yer vermiştir (bkz. Şekil 28). Çizdiği bardak modeli sadece içtiği suyu temsil eden ve çözüm için gereksiz olan bir gösterimdir. Ayrıca, çözümde kastedilen 1 bardak su, gerçek yaşamda 1 litre değildir. 


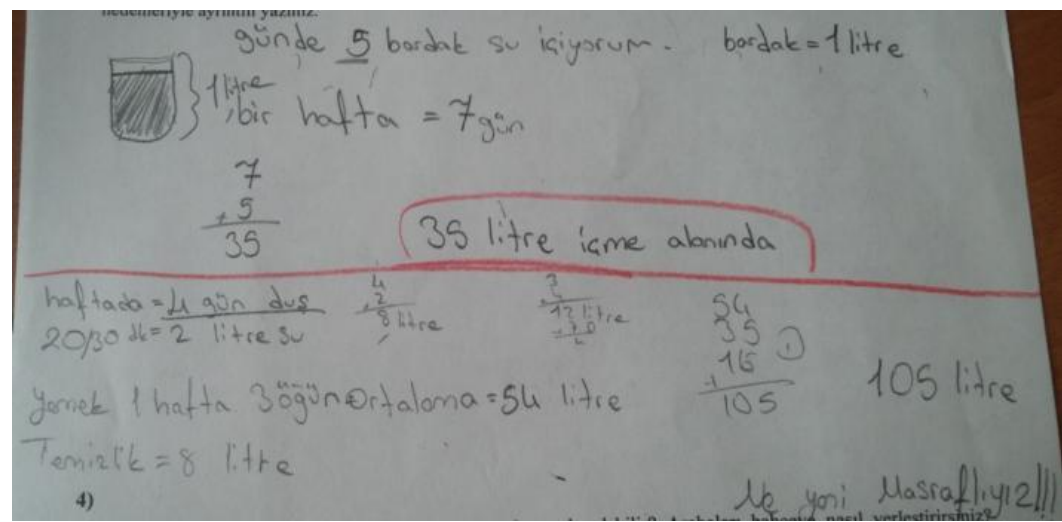

Şekil 28. Ö1'in Su Harcama Problemi'ne ilişkin çözümü

$\mathrm{Bu}$ aşamada modelin oluşturulmasında öğrencinin gerçek yaşam deneyimi doğrultusunda yapmış olduğu tahmin yanlıştır ve bu da onun varsayımını etkileyerek etkili bir model ve matematiksel çözüm elde etmesini engellemiștir. Bunun yanında, suyun farklı kullanım alanlarını liste şeklinde görselleștirmiș ve çözümünü bu model üzerinde sürdürmüștür. Bu durum, öğrencilerin modelleme sürecinde aynı çözüm içerisinde gerekli gördüklerinde farklı türdeki gerçek yaşam problem durumu modellerine yer verdiklerini göstermiştir.

\section{Gerçek Yaşam Problem Durumu Modelinin Modelleme Sürecinde Kullanımı}

Öğrenciler, oluşturdukları gerçek yaşam problem durumu modellerini temelde üç farklı şekilde kullanmışlardır. Bunlar; matematiksel çözüme ulaşma, matematiksel sonuçlara ulaşma ve yorumlama yapmadır. Öğrencilerin genel olarak, modelleme sürecinde basit matematiksel işlemlerden, çözümü ilerletemedikleri durumlarda da gerçek yaşam problem durumu modelinden yararlanarak gerekçelendirilmiş/gerekçelendirilmemiş tahmin yapma yoluna gittikleri belirlenmiştir. Öğrenciler çözümlerinde oluşturdukları gerçek yaşam problem durumu modellerini en çok matematiksel çözüme ulaşmak için kullanmışlardır.

Öğrencilerin çözümleri incelendiğinde, öğrenciler modelleme sürecinde matematiksel modeli net olarak gözlenebilir şekilde oluşturamamışlar; bunun yerine, stratejik etkenler arasındaki ilişkileri zihinsel olarak yapılandırarak matematiksel ilișkileri ortaya koymuşlar ve matematiksel çözüme ulaşmayı temel hedef olarak görmüşlerdir. Modelleme sürecinin önemli bir bileşeni olan matematiksel modeller onların çözümlerinde daha ilkel bir şekilde ortaya çıkmış ve matematiksel çözüm, sonuçlar ve yorumlamalara firsat sağlamıştır. Bu durum, öğrencilerin düzeyi (altıncı sınıf), modellemedeki deneyimleri ve modelleme yeterliklerinin düzeyi dikkate alındığında beklenen bir durum olarak değerlendirilmiștir.

\section{Matematiksel Çözüme Ulaşma}

Öğrenciler oluşturdukları gerçek yaşam problem durumu modelinden hareketle problemde istenilen matematiksel çözümü bulmaya çalışmışlardır. Bu süreçte, basit matematiksel işlemler veya tahminler yardımıyla oluşturdukları matematiksel ilişkiler onlar için çözümde önemli olmuştur. Öğrencilerin büyük bir kısmı (\% 78) bir şekilde elde ettikleri matematiksel çözüme ulaştıklarında çözümü bırakmışlardır. Öğrenciler çözümlerinde stratejik etkenler arasındaki matematiksel ilişkileri ortaya çıkaramasalar da, matematiksel çözüme (istenen değer) ulaşmak için gerekçelendirilmemiş tahminlerle bir sayısal değer yazmaya çalışmışlardır. Öğrencilerin modelleri ideale yakın olsa da bazen işlem hatalarından dolayı ve matematiksel ilişkiyi tam olarak ortaya çıkaramadıkları için yanlış matematiksel çözümlere ulaştıkları da görülmüştür. Örneğin, Ö 42 Sınıf Mevcudu Problemi'ne ilişkin çözümünde, liste türündeki gerçek yaşam problem durumu modelinde stratejik etkenleri doğru olarak yapılandırsa da stratejik etkenler arasındaki matematiksel ilişkilendirmeyi yanlış kurduğu için yanlış matematiksel çözüme ulaşmıştır (bkz. Şekil 29). Bir başka ifadeyle, Ö$_{42}$ gerçek modelini matematiksel çözüme ulaşmada etkili bir șekilde kullanamamıştır. 


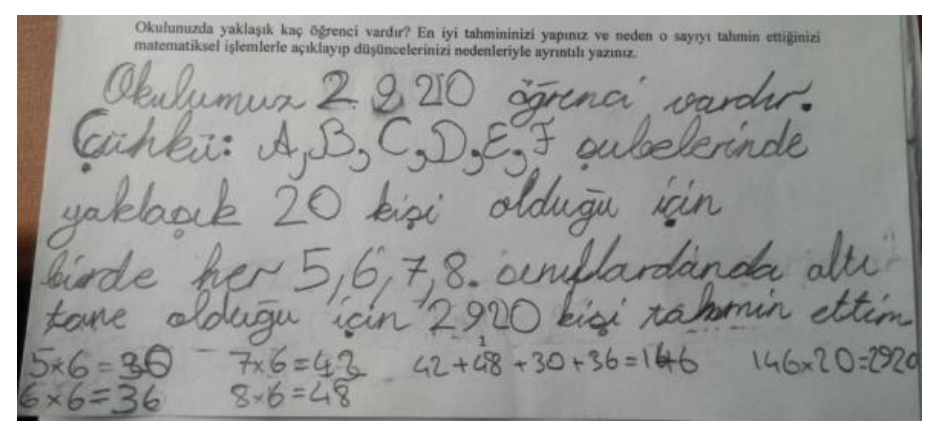

Şekil 29. $\ddot{A 2}_{42}$ nin Sinıf Mevcudu Problemi'ne ilişkin çözümü

Farklı çözümler incelendiğinde, 23 öğrencinin yaptığı 53 çözümde öğrencilerin Ö$_{64}{ }^{\prime}$ ün çözümündeki gibi hiçbir gerekçelendirme yapmadan çözümlerini sonlandırdıkları ve matematiksel çözümlerini elde ettikleri belirlenmiştir (bkz. Şekil 30). Öğrencilerin problemi anlamadıkları için gerçek yaşam problem durumu modelini oluşturamamalarının ve stratejik etkenler arasındaki matematiksel ilişkileri ortaya koyamamalarının nitelikli matematiksel çözüme ulaşmalarını engellediği söylenebilir.

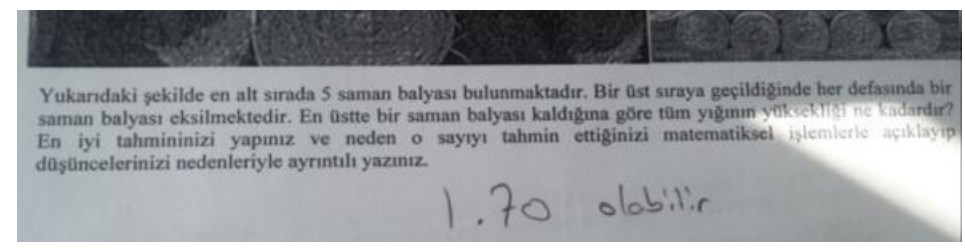

ŞEKİL 30. Ö64'ün Saman Balyası Problemi'ne ilişkin çözümü

Bunun yanı sıra; etkili gerçek yaşam problem durumu modellerinin yardımıyla ve matematiksel ilişkileri ortaya çıkararak diğerlerine göre daha nitelikli matematiksel çözümlere ulaşan öğrenciler de olmuştur. Örneğin, Ö̈ ${ }_{3}^{\prime}$ ün Saman Balyası Problemi'ne ilişkin çözümü incelendiğinde, $\mathrm{O}_{3}$ matematiksel çözümün beş saman balyasının yüksekliği kadar olduğunu ifade etmiş ve matematiksel çözümü olacak sayısal değere fotoğraftaki çocuğun üst kısmının $65 \mathrm{~cm}$ olduğu ve bunun da bir saman balyasının yarıçapına denk geldiği düşüncesiyle ulaşmıştır (bkz. Şekil 31).

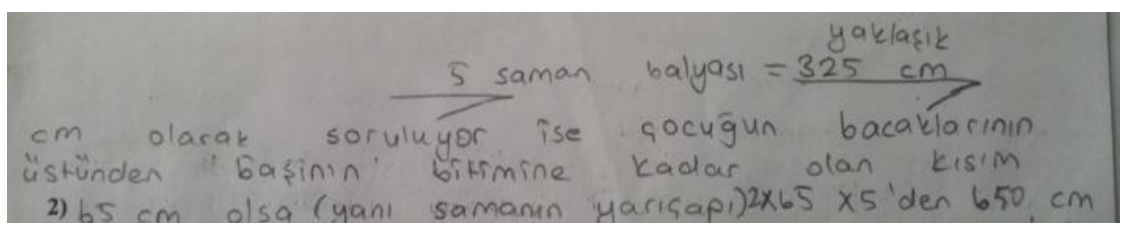

Şekil 31. Ö3'ün Saman Balyası Problemi'ne ilişkin çözümü

Ö$_{3}$ 'e göre yükseklik (matematiksel çözüm) $650 \mathrm{~cm}$ olarak ifade edilmiştir. Daha nitelikli bir çözümde ise yüksekliğin beş saman balyasının yüksekliğinden daha küçük olduğunu söylemeleri beklenmiştir. Öğrencilerin ise çözümlerinde bu düşünceyi ortaya çıkaramadığı görülmüştür. Bu durumun oluşmasında öğrencilerin matematiksel bilgilerinin kısıtlı olması gerekçe olarak gösterilebilir. Fakat yeterli modelleme deneyimi kazanmış altıncı sınıf öğrencilerinin bu değerin daha az olacağına sezgisel tahminleriyle ulaşabilecekleri de söylenebilir.

\section{Matematiksel Sonuçlara Ulaş̧ma}

Öğrencilerin oluşturdukları gerçek yaşam problem durumu modelinden hareketle problemde istenilen sonuç olan matematiksel çözümden farklı olarak, problemdeki farklı durumları açıklayan bazı sayısal değerleri de buldukları belirlenmiştir. Bu süreçte basit matematiksel işlemler veya tahminler onlar için önemli olmuştur. Örneğin, Ö ${ }_{11}$ 'in Su Harcama Problemi'ne ilişkin çözümü incelendiğinde, farklı amaçlar için bir hafta boyunca kaç litre su tükettiğini ayrı ayrı ifade ettiği görülmüştür (bkz. Şekil 32). Ö ${ }_{11}^{\prime}$ e göre su; içme, duş, yemek ve temizlik için kullanılmaktadır. Her biri için bulduğu matematiksel sonuçlar Ö$_{11}$ 'in matematiksel çözüme ulaşmasını sağlamıştır ve çözümü 
sonlandırmadan çok fazla su harcadığını ifade eden "Masraflıyız!" ifadesini kullanarak bulduğu matematiksel çözüm ve sonuçları yorumlamıştır.

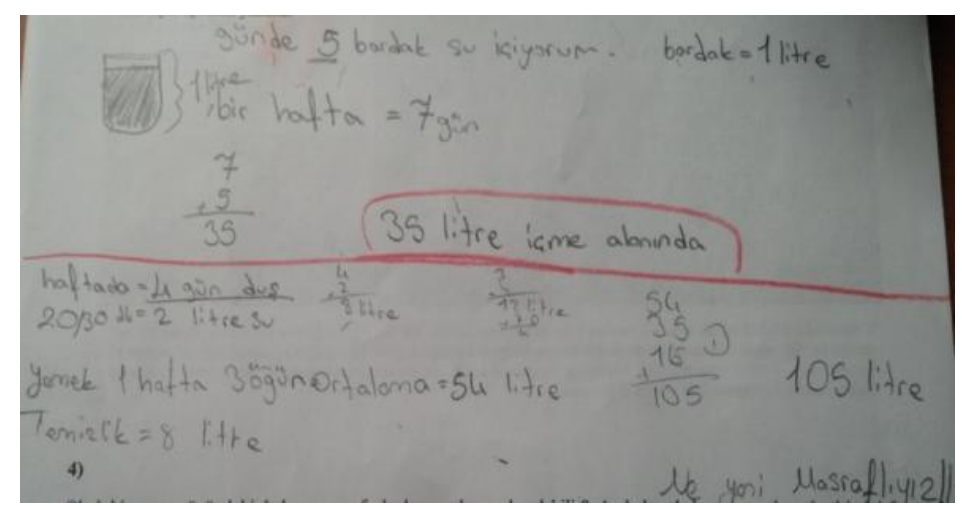

Şekil 32. Ö11'in Su Harcama Problemi'ne ilişskin çözümü

$\mathrm{Ö}_{3}{ }^{\prime}$ ün Sınıf Mevcudu Problemi'ne ilişkin çözümü incelendiğinde, $\mathrm{O}_{3}$ anasınıfındaki öğrenci sayısını (matematiksel bir sonuç) dikkate alarak daha nitelikli bir matematiksel çözüme ulaşmıştır (bkz. Şekil 33). Ayrıca sabahçı ve öğlenci öğrenci sayıları da onun ulaştığı matematiksel sonuçlardan bazılarıdır ve matematiksel çözüme ulaşmasında ona yardımcı olmuştur.

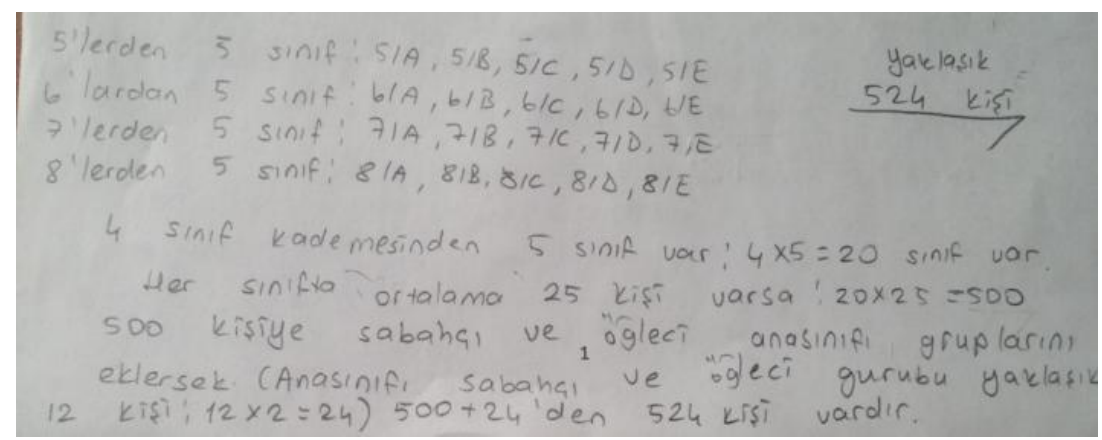

Şekil 33. Öз'ün Sinıf Mevcudu Problemi'ne ilişkin çözümü

“ $\ddot{O}_{3}$ "Araçlar arasındaki mesafe vardır ama çok azdır. Onu hesaba almaya gerek yok. $O$ zaman çok zor olur dimi hocam?" diyerek öğretmeninden cevap almaya çalıștı. Öğretmeni "Hangisini yapmak istiyorsan onu yapabilirsin." dedi. (Gözlem Notu A: C Ortaokulu)

\section{Yorumlama}

Öğrencilerin oluşturdukları gerçek yaşam problem durumu modelinden hareketle bazı sayısal değerlere ulaşmaya çalıştıkları ve bu sayısal değerleri de gerçek yaşam durumu bağlamında basit düzeyde yorumladıkları görülmüștür. Örneğin Ö ${ }_{11}$, matematiksel çözümünü 24 olarak ifade ettikten sonra not düşerek arabanın büyük, (Burada Ö$_{11}$ araba ile her türlü taşıtı kastediyor. Gözlem Notu B: C Ortaokulu), bahçenin ise küçük olduğu durumların çözümde sorun olabileceğini ifade etmiştir (bkz. Şekil 34). Yani, o zaman 24 arabanın bahçeye sığmayabileceğini vurgulamıştır. Basit düzeyde bir yorumlama söz konusudur.

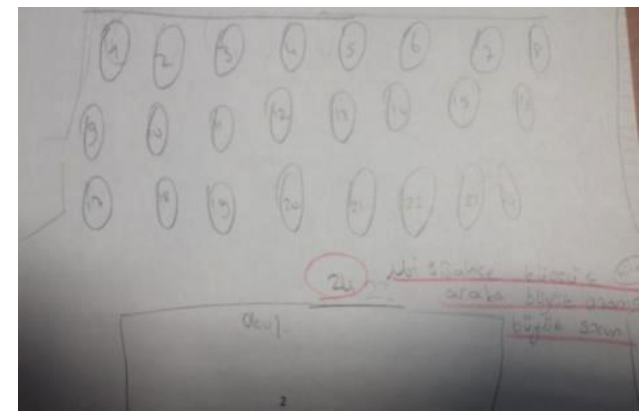

Şekil 34. $\ddot{O}_{11}$ 'in Otopark Problemi'ne ilişkin çözümü 
$\ddot{O}_{11}$ "Araçlar arasında uzaklık var. Bir de her araç buraya park edebilir. Burada aynı gibi çizdim ama farklı olabilir. Kamyon da olabilir. Motor da. Kamyon olursa bu kadar araba park edemez. Daha az olur. Mesela 18" diyerek bulduğu matematiksel çözüm üzerinden bazı yorumlamalara gitmiștir." dedi. (Gözlem Notu A: C Ortaokulu)

$\ddot{O}_{5}$ 'in ve Ö$_{52}$ 'nin Su Harcama Problemi'ne ilişkin çözümlerinde, gereksiz yorumlara yer verdikleri görülmüştür (bkz. Şekil 35 ve Şekil 36). Ayrıca, buldukları matematiksel çözümleri gerekçelendirecek açıklamalar yapmamışlar ve gerekçelendirilmemiş tahminlerde bulunarak nitelikli bir çözüm elde edememişlerdir.

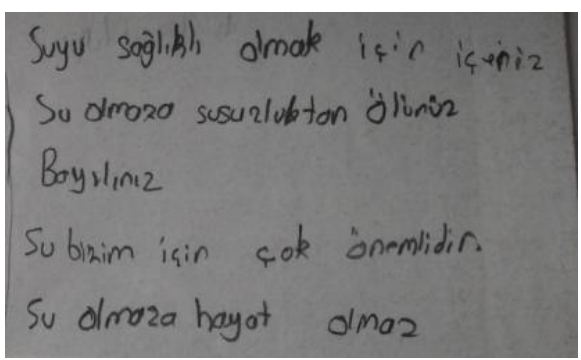

Şekil 35. Ö5'in Su Harcama Problemi'ne ilişkin çözümü

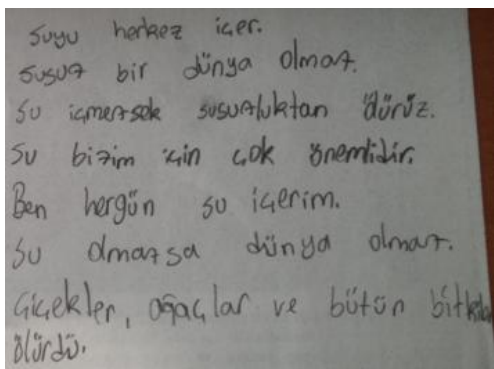

Şekil 36. Ö52'nin Su Harcama Problemi'ne ilişkin çözümü

Ö 20 'nin Okul Mevcudu Problemi'ne ilișkin çözümü incelendiğinde, matematiksel çözüm olarak bulduğu 540'ı öncelikle yuvarlayarak yaklaşık 550 öğrenci vardır șeklinde ifade etmiştir (bkz. Şekil 37). Ayrıca Ö 20 , farklı bir yol olan öğrenci numaralarından hareketle bir tahminde bulunmaya çalışarak bulduğu 550 değerini mantıksal olarak doğrulamaya çalışmıștır. Altıncı sınıfta modellemede deneyimsiz öğrencilerden doğrulama yaklaşımlarının çıkması öğrencilerin gerekli deneyimlerle modelleme yeterliklerinin istenilen düzeye çekilebileceğini göstermiştir.

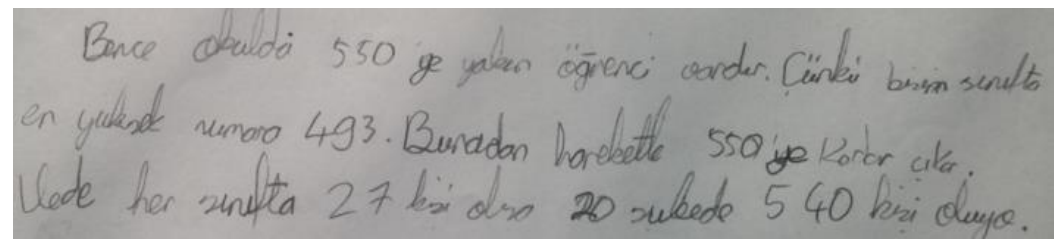

Şekil 37. ${ }_{20}$ 'nin Okul Mevcudu Problemi'ne ilișkin çözümü

“Ö${ }_{20}$ gerekli işlemlerle matematiksel çözümü 540 olarak buldu. ... Matematiksel çözümü "yaklaşık 550 öğrenci vardır. ... Öğrenci numaralarından hareketle öğrenci sayısını tahmin etmeye çalışıyor. ... Matematiksel çözümünü bu şekilde tatmin edici buluyor." (Gözlem Notu B: C Ortaokulu)

Ö$_{1}$ 'in Okul Mevcudu Problemi'ne ilişkin çözümü incelendiğinde, matematiksel çözümünün yanına "ortalama" ifadesini yazdığı görülmüştür (bkz. Şekil 38).

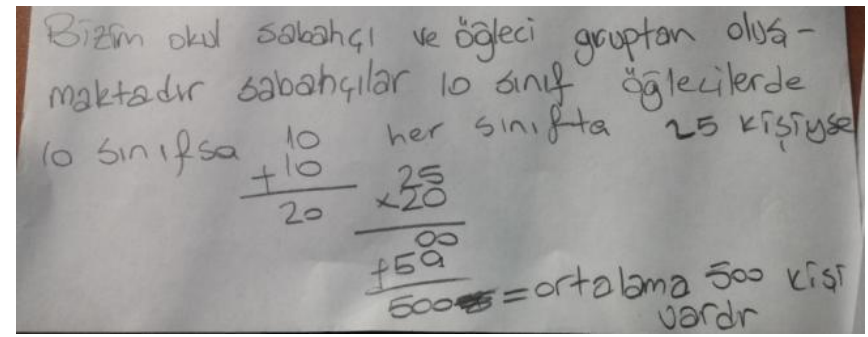

Şekil 38. Ö$_{1}$ in Okul Mevcudu Problemi'ne ilişkin çözümü

$\mathrm{Bu}$ öğrencinin bulduğu matematiksel çözümünün tam olmadığının ve gerçek sonucun bu değere yakın bir değer olduğunu bildiğinin bir göstergesidir. Bunun gibi öğrencilerin çözümlerinde "yaklaşık", "ortalama", "bu değere yakın" gibi ifadeler kullandıkları ve buldukları sayısal değerin gerçek yaşamdaki karşıllğını yorumladıkları görülmüştür. 


\section{TARTIŞMA ve SONUÇ}

Altıncı sınıf öğrencilerinin matematiksel modellemedeki gerçek yaşam problem durumu modellerinin türlerinin, bu modelleri oluşturan etkenlerin ve modelin süreçteki kullanımının incelendiği çalışmada, içerik analiziyle farklı kategorilere ulaşılmıştır. Gerçek yaşam problem durumu modelinin yapısını etkileyen faktörler problem kaynaklı ve öğrenci kaynaklı faktörlerdir. Problem kaynaklı faktörler, problem içeriği; öğrenci kaynaklı faktörler, problemi anlama, gerçek yaşam deneyimi, tahmin/ölçüm ve matematiksel önbilgi olmuştur. Gerçek yaşam problem durumu modeli resim, şekil ve tablo/liste olmak üzere üç farklı türde ortaya çıkmıştır. Gerçek model, süreçte matematiksel çözüme ulaşma, matematiksel sonuçlara ulaşma ve yorumlama olmak üzere üç farklı şekilde kullanılmıştır.

Modellemede, öğrenciler stratejik etkenleri ortaya çıkarmakta zorlanmışlardır. Öğrencilerin çözümlerinde gereksiz verilere ilişkin düşünceler açığa çıkarmaları problemi anlamadıklarının göstergelerinden birisi olmuştur. Özellikle öğrenciler gerçek yaşam deneyimlerinden daha uzak bir problem olan Saman Balyası Problemi'ni anlamakta zorlanmışlardır. Maaß (2006) ve Lesh ve Caylor (2007), öğrencilerin gerçek yaşam bilgi ve deneyimlerine dayalı durumların öğrenciler tarafından daha kolay anlamlandırıldığını ve öğrencilerin daha gerçekçi modeller ve çözüm elde etmesinde önemli bir etken olduğunu ifade etmektedir. Öğrenciler bu problemde problemi tam olarak anlamamışlar ve matematikle gerçek yaşam arasındaki ilişkiyi kuramadıkları için oran kavramını bildikleri halde etkili olarak problemde kullanamamışlardır. Bu nedenle, Lamberts (2005), English (2003), Lesh ve Doerr (2003), Peter Koop (2004), Ärlebäck'in (2009) düşüncelerine paralel olarak, öğretmenlerin modelleme destekli öğrenme ortamlarında öğrencilerin yaşamlarındaki olaylardan esinlenmelerinin, onların zihinsel süreçlerini açığa çıkaracak ve geliştirecek daha zengin ortamlar sağlayacağı söylenebilir.

Öğrenciler, çözümlerinde gerçek modellerini oluşturacak stratejik etkenlere ilişkin tahminler yapmaya çalışsalar da, gerçekçi tahminlerde bulunamamışladır. Elde ettikleri gerçek model, yorumlama basamağında gerçek yaşam çözümleri/sonuçları ile matematiksel çözümleri/sonuçları arasındaki ilişkiyi ortaya çıkardığı için gerçek modelin ölçeklendirilmesinde ilk aşamada yapılan bu tahminler önemli rol oynamaktadır (Hıdıroğlu, 2015). Öğrencilerin gerçekçi tahminlerde bulunamamaları çözümlerinde gerçekçi bir modele ulaşmalarını engellemiştir. Bu durumun oluşmasındaki temel faktörler, hem öğrencilerin bu tür ortamlarla baş başa kalmaması hem de matematiksel ölçülerin gerçek yaşamdaki karşılıklarını bilmemeleridir. Öğrencilerin bu aşamada uzunluk, ağırlık gibi kavramları karıştırdıkları ve hatalı/gerekçelendirilmemiş tahminlerde bulundukları görülmüştür. Öğrenciler modellemede gerekçelendirilmemiş tahminlerle gerçek modele ve matematiksel çözüme ulaşma yoluna gitmiş ve matematiksel düşüncelerini açılamakta zorlanmışlardır. Maaß $(2005,2006)$, Kaiser (2007) ve Blum (2011) da matematiksel modellemede öğrencilerin varsayımları oluştururken gerçekliği çok fazla göz önüne almadıklarını ve problemde doğrudan verilmeyen stratejik etkenlere ilişkin tahminlerde gerçek değerlere yaklaşamamalarının varsayımlarını ve dolayısıyla gerçek modellerini etkilediğini ifade etmektedir. Borromeo Ferri (2006) ve Hıdıroğlu'nun (2015) ifade ettiği gibi, çalışmada öğrencilerin tahminleri sezgilerinden ve bilgilerinden hareketle ortaya çıkmıştır. Treilibs, Burkhardt ve Low (1980), Schoenfeld (1985) ve Hıdıroğlu ve Bukova Güzel (2016), tahmin eylemlerinin süreçteki üst bilişsel eylemlerden bazıları olduğunu ifade etmekte ve MEB (2013) Ortaokul Matematik Dersi Öğretim Programı'nda tahmin becerileri temel becerilerden biri olarak kabul edilmektedir. Bu nedenle, modelleme problemlerinde, Fermi problemleri gibi öğrencilerin tahminde bulunabilecekleri ortamlar yaratılmalıdır.

Öğrencilerin gerçek yaşam problem durumu modellerini etkileyen faktörlerden biri de gerçek yaşam deneyimleridir. Bu durum, öğrencilerin varsayımlarını ve kısıtlamalarını şekillendirmiş ve dolayısıyla gerçek modelin yapısını etkilemiştir. Deneyimler, süreci olumlu hale getirse de öğrencilerin bazı durumlarda yaptıkları kısıtlamalara ilişkin daha esnek bir bakış kazanamadıkları ortaya çıkmıștır. Modellemeye ilişkin deneyim kazanmalarının bu durumu ortadan kaldırabileceği söylenebilir. Aynı şekilde Cox (1999), Pólya (1945), Abrams (2001), Biccard ve Wessels (2011), Şen Zeytun (2013), Blum (1996), Kaiser-Meßmer (1986), Hıdıroğlu (2015), Hıdıroğlu ve Bukova Güzel (2016) de gerçek yaşam deneyimlerinin gerçek modelleri elde etmede ve çözüme ulaşmada bir araç olarak kullanıldığını ifade etmektedir. 
Öğrenciler modellemede zihinsel modellerini gerçek yaşam problem durumu modellerine tam olarak yansıtamamışlar ve gerçek modellerinde çözüm için gereksiz çizimlere yer vermişlerdir. Bu süreçte Crouch ve Haines (2004), Ikeda ve Stephens (2001), Ji (2012) ve Niss'e (2001) paralel olarak, öğrencilerin problemi anlama, sadeleştirme, varsayımda bulunma süreçlerini içeren gerçek yaşamdan matematiğe geçişte zorlandıkları belirlenmiştir.

Modelleme sürecinde oluşturulan gerçek yaşam problem durumu modelleri Cai (2005), Goldin ve Shteingold (2001), Janvier ve Bednarz'in (1987) ifade ettiği dışsal temsiller olarak karşımıza çıkmıştır. Gerçek modeller, modelleme sürecinde oluşturulan zihinsel modellerin görsel veya sembolik hale getirilmesiyle elde edilen modellerdir. Gerçek yaşam problem durumunun modeli, çalışmada Diezmann ve English (2001), Elia ve diğerleri (2007), Neria ve Amit (2004) ve Preston ve Garner'ın (2003) ifade ettiği temsil türlerinden tablo ve şekil olarak ortaya çıkmıştır. Ayrıca çalışmada gerçek yaşam problem durumu modelleri Montegue'nun (2008) ifade ettiği gibi, resim ve şekil türünde iki farklı şekilde ortaya çıkmıştır. Resim, öğrencilerin gerçek yaşamdaki durumu zihinde ilk hatırladığı haliyle dışsal temsil haline getirmesiyle; şekil ise, öğrencilerin görev ve bilgilerini dikkate alarak gerçek yaşam problem durumunu anlamlı bir şekilde dişsal temsil haline getirmesiyle ortaya çıkmıştır. Modellemede öğrencilerin oluşturduğu resim türündeki gerçek yaşam problem durumu modelleri çözüm için çok uygun olmayan ve yeni bilgileri dikkate almayarak geçmiş deneyim ve bilgilerle elde edilen, düşük düzeyde düşünme süreçlerini içeren bir süreci içermektedir. Problem çözmede başarılı olan öğrenciler, dışsal temsil olarak resim değil, şekil türünde gerçek modeller oluşturmuşlardır. Modelleme problemlerini temsil etmekte zorlanan öğrenciler genellikle resim türünde modeller çizerek sürecin ileriki basamaklarına geçememişlerdir. Alanyazındaki diğer temsil türlerinin olmamasında öğrencilerin sahip oldukları modelleme yeterlikleri, deneyimleri ve matematikteki düzeylerinin etkili olduğu söylenebilir.

Öğrenciler Saman Balyası ve Otopark Problemi'nde genellikle resim ve şekil türünde gerçek modeller ortaya koyarlarken, Su Harcama ve Okul Mevcudu Problemi'nde tablo/liste türünde gerçek modellere daha çok yer vermişlerdir. Bu durum, öğrencilerin oluşturdukları modellerin problemin içeriğinden etkilendiğini göstermiştir. Genellikle, geometri bilgisi gerektiren problem durumlarında öğrencilerin resim ve şekillerle gerçek modellerini açıklamaya çalıştıkları söylenebilir. Öğretim programında öğrencilerden somut model, şekil, resim, grafik, tablo, sembol vb. farklı temsil biçimlerini kullanarak matematiksel düşüncelerini ifade etmeleri beklenmektedir (MEB, 2013). Bu nedenle, öğrenme süreçlerinde onların somut ve soyut temsil biçimleri (tablo, grafik, denklem, şekil, somut modeller, semboller, gerçek yaşam durumları, vb.) arasında ilişkilendirme yapabilecekleri ve çeşitli türlerde gerçek modeller oluşturulacakları modelleme problemlerini içeren ortamlar hazırlanmalıdır.

Öğrenciler gerçek modeli süreçte çoğunlukla matematiksel çözüme ulaşmak için kullanmaya çalışmışlardır. Modellemede nitelikli gerçek yaşam problem durumu modelleri oluşturan öğrencilerin genellikle nitelikli bir sonuca ulaşabildikleri görülmüştür. Paralel olarak, Cifarelli (1998) de problem çözmede başarının büyük oranda probleme uygun temsilleri oluşturmayla ilgili olduğunu belirtmektedir. Cai ve Lester (2005) da, problem çözme sürecinde başarılı olan öğrencilerin ortak özelliklerinin dışsal temsilleri oluşturan ve bunları doğru yerlerde kullanabilen kişiler olduklarını ifade etmektedir. Montegue'nün (2008) ifade ettiği gibi, bazı durumlarda temsilleri oluşturup ileriki basamaklarda temsili gerektiği gibi kullanamayan bazı öğrenciler modellemede başarısız olmuşlardır. Bunun yanında, gerçek model oluşturamayan öğrencilerin de gerekçelendirilmemiş tahminlerle bir şekilde sayısal bir değere (matematiksel çözüm) ulaşmaya çalıştıkları belirlenmiştir. Bu durum, eğitim sisteminin öğrencilerin matematiksel çözüme ulaşmalarını önemli kılmasının sonucu olduğu söylenebilir. Modelleme sürecine bakıldığında, ortaokul düzeyindeki öğrencilerin matematiksel ilişkileri basit bir düzeyde kurmaya çalıştıkları görülmüştür. Öğrencilerin modelleri üzerinden yüzeysel matematiksel ilişki, işlem ve yorumlar yapmaları onların ilerleyen basamaklarda beklenen düzeyde başarılı olmalarını engellemiştir. Biccard ve Wessels (2011) ve Blum (2011) da öğrencilerin ilk aşamalarda daha basit ve yüzeysel matematiksel ilişkiler oluşturduklarını söylemektedir. Modellemede daha fazla deneyim kazanacak ve becerileri geliștirilecek öğrencilerin, matematiksel ilișkileri veya matematiksel modelleri oluşturmada daha başarılı olmaları beklenmektedir. Bununla birlikte, çalışmada gerçek model yardımıyla matematiksel sonuçlar elde eden öğrenci sayısı oldukça az olmuştur ve öğrenciler bazen 
çözümleriyle ilgili basit yorumlarda bulunmuşlardır. Öğrencilerin matematiksel sonuçlara ulaşmak için bir çabası olmamış ve bazı öğrenciler matematiksel çözüme olan etkisinden dolayı bazı matematiksel sonuçlara nadiren yer vermişlerdir. Ayrıca Blum (2011), Ji (2012), Maaß (2006) ve Sekerak'ın (2010) ifade ettiği gibi, öğrenciler matematiksel çözümleri/sonuçları yorumlamada sıkıntılar yaşamışlardır.

Öğrencilerin sahip oldukları yeterlik düzeylerine bakıldığında, matematiksel modelleme matematik dersi öğretim programlarında yer ve önem verilen programa entegre edilmiş bir konu olurken, öğrencilerin matematiksel modelleme konusunda yeterli deneyime sahip olmadıkları ve derslerde modelleme problemlerinin kullanılmadığı (Blum, 2002; Borromeo Ferri, 2010; Mousoulides, Christou ve Sriraman, 2006; Turner, 2007) belirlenmiștir. Blum (2002) ve Borromeo Ferri'nin (2009) ifade ettiği gibi, daha önce hiç modelleme uygulamaları üzerinde çalışmamış olan öğrencilerin problemlerin açık uçlu yapısına alışkın olmadıkları ve problem ile çözümü arasında ilişki kurmakta zorlandıkları belirlenmiştir. $\mathrm{Bu}$ zorluğu aşmalarında araştırmada yer verilen Okul Mevcudu ve Otopark Problemi gibi onların gerçek yaşam deneyimlerine sahip oldukları modelleme problemleri etkili olmuştur.

İleriki çalıșmalarda, modelleme sürecindeki zihinsel modelin modellemedeki etkisi, zihinsel modellerle (iç temsil) gerçek yaşam problem durumu modelleri (dıș temsil) arasındaki ilişki ve modelleme sürecindeki iç veya dış temsillerin birbirlerine etkisi klinik mülakatlarla ortaya çıkarılabilir. Bu doğrultuda, temsillere ilişkin gerekli modelleme yeterlikleri doğrultusunda atomistik veya bütüncül anlayışla tasarlanacak öğrenme etkinliklerinin gerekli yeterlikleri öğrencilerin kazanmalarındaki etkisi karma araştırma yöntemleriyle incelenebilir. Modelleme problemiyle birlikte verilebilecek farklı temsillerin süreçteki diğer temsil türleri ve modellemedeki zihinsel süreçleri ortaya çıkarmada etkisine bakılabilir.

\section{KAYNAKÇA}

Abrams, J. P. (2001). Mathematical modeling: Teaching the open-ended application of mathematics. 12 Eylül 2015 tarihinde http://www.meaningfulmath.org/modelingcycle.pdf adresinden erişilmiștir.

Aiken, L. R. (1997). Qustionnaires and inventories: Surveying opinions and assessing personality. New York: John Wiley \& Sons.

Ang, K. C. (2001). Teaching Mathematical Modelling in Singapore Schools. The Mathematics Educator. 6(1), 63-75.

Ang, K. C. (2006). Mathematical modelling, technology and H3 mathematics. The Mathematics Educator, 9(2), 33-47.

Ang, K. C. (2010). Teaching and learning mathematical modelling with technology. Nanyang Technological University. 20 Mart 2012 tarihinde http://atcm.mathandtech.org/ep2010/invited/3052010_18134.pdf adresinden erişilmiştir.

Ärlebäck, J. B. (2009). On the use of realistic Fermi problems for introducing mathematical modelling in school. The Montana Mathematics Enthusiast, 6(3), 331- 364.

Biccard, P. ve Wessels, D. C. J. (2011). Documenting the development of modelling competencies of grade 7 mathematics students. International Perspectives on the Teaching and Learning of Mathematical Modelling, 1(5), 375-383.

Blomhøj, M. (2008). Different perspectives on mathematical modelling in educational research - Categorising the TSG21 papers. M. Blomhøj ve S. Carreira (Eds), Mathematical applications and modelling in the teaching and learning of mathematics (ss. 1-18) içinde. 8 Ocak 2015 tarihinde http://milne.ruc.dk/imfufatekster/pdf/461.pdf adresinden erişilmiştir.

Blum, W. (1985). Anwendungsorientierter mathematikunterricht in der didaktischen diskussion. Mathematische Semesterberichte, 32, 195-232.

Blum, W. (1996). Anwendungsbezüge im mathematikunterricht - Trends und pesrpetiven. Trends und Perspektiven. Schriftenreihe Didaktik Der Mathematik, 23, 15-38.

Blum, W. (2002). ICMI Study 14: Applications and modelling in mathematics education-Discussion document. Educational Studies in Mathematics, 51(1), 149-171.

Blum, W. (2011). Can modelling be taught and learnt? Some answers from empirical research. G. Kaiser, W. Blum, R. Borromeo Ferri ve G. Stillman (Eds), Trends in the teaching and learning of mathematical modelling - Proceedings of ICTMA14 (pp. 15-30) içinde. New York: Springer.

Blum, W. ve Leiß, D. (2007). How do students and teachers deal with mathematical modelling problems? The example "Sugarloaf". C. Haines, P. Galbraith, W. Blum, ve Khan, S. (Eds), Mathematical modelling (ICTMA 12): Education, engineering and economics, (ss 222-231) içinde. Chichester: Horwood Publishing.

Borromeo Ferri, R. (2006). Theoretical and empirical differentiations of phases in the modelling process. Zentralblatt für Didaktik der Mathematik, 38(2), 86-95.

Borromeo Ferri, R. (2007). Personal experiences and extra-mathematical knowledge as an influence factor on modelling routes of pupils. D. Pitta-Pantazi ve G. Philippou (Eds), Proceedings of the Fifth Congress of the European Society for Research in Mathematics Education (ss. 2080-2089) içinde. Larnaca: Zypern.

Borromeo Ferri, R. (2010). On the influence of mathematical thinking styles on learners' modeling behaviour. Journal für Mathematikdidaktik, 31(1), 99-118. 
Brenner, M. E., Mayer, R. E., Moseley, B., Brar, T., Durán, R., Reed, B. S. ve Webb, D. (1997). Learning by understanding: The role of multiple representations in learning algebra. American Educational Research Journal, 34(4), 663-689.

Cai, J. (2005). US and Chinese teachers' constructing, knowing and evaluating representations to teach mathematics. Mathematical Thinking and Learning. 7(2), 135-169.

Cai, J. ve Lester, F. K. (2005). Solution representations and pedagogical representations in Chinese and U. S. classrooms. Journal of Mathematical Behavior, 24, 221-237.

Carlson, M., Larsen, S. ve Lesh, R. (2003). Integrating a models and modeling perspective with existing research and practices. R. Lesh ve H. Doerr (Eds), Beyond constructivism: Models and modeling perspectives on mathematics problem solving, learning, and teaching (ss. 465-478) içinde. Hillsdale, NJ: Lawrence Erlbaum Associates.

Charmaz, K. (2006). Constructing grounded theory / A practical guide through qualitative analysis. London: Sage Publications Ltd.,

Cifarelli, V. V. (1998). The development of mental representations as a problem solving activity, Journal of Mathematical Behavior. 17(2), 239-264.

Cox, R. (1999). Representation construction, externalised cognition and individual differences. Learning and Instruction, 9 , 343-363.

Crouch, R. ve Haines, C., (2004). Mathematical modeling: Transitions between real world and the mathematical model. Instructional Journal of Mathematical Education in Science and Technology, 35(2), 197-206.

Diezmann, C. M. ve English, L. D. (2001). Promoting the use of diagrams as tools for thinking. A. A. Cuoco ve F. R. Curcio (Eds), The roles of representation in school mathematics: 2001 yearbook (pp. 77-89) içinde. Reston, VA: National Council of Teachers of Mathematics.

Eisner, E. W. (1997). Cognition and representation. Phi Delta Kapan. 78(5), 348-353.

Elia, I, Gagatsis, A. ve Demetriou, A. (2007). The effects of different modes of representation on the solution of one-step additive problems. Learning and Instruction, 17, 658-672.

English, L. D. (2003). Mathematical modelling with young learners. S. J. Lamon, W. A. Parker ve S. K. Houston (Eds), Mathematical modelling: A way of life (ss. 3-18) içinde. Chichester: Horwood Publishing.

Fennell, F. S. ve Rowan T. (2001). Representation: An important process. Teaching and Learning Mathematics, 7(5), 288292.

Galbraith, P. ve Stillman, G. (2006). A Framework for identifying student blockages during transitions in the modelling process. Zentralblatt für Didaktik der Mathematik-ZDM, 38(2), 143-162.

Galbraith, P., Stillman, G., Brown, J. ve Edwards I. (2007). Facilitating middle secondary modelling competencies. C. Haines, P. Galbraith, W. Blum ve S. Khan (Eds), Mathematical Modelling: ICTMA 12: Education, Engineering an Economics, (ss. 130-140) içinde. Chichester: Horwood Publishing.

Goldin, G. ve Shteingold, N. (2001). Systems of representations and the development of mathematical concepts. A. Cuoco ve F. Curcio (Eds), The roles of representation in school mathematics (ss. 1-23) içinde. Va: Reston Virginia, NCTM Yearbook

Greeno, G. ve Hall, R. P. (1997). Practicing Representation: Learning with and about Representational Forms. Phi Delta Kappan, 78(5) , 361-367.

Hıdıroğlu, Ç. N. (2012). Teknoloji destekli ortamda matematiksel modelleme problemlerinin çözüm süreçlerinin analiz edilmesi: Yaklaşım ve düşünme süreçleri üzerine bir açıklama. Yayımlanmamış yüksek lisans tezi, Dokuz Eylül Üniversitesi, İzmir.

Hıdıroğlu, Ç. N. (2015). Teknoloji destekli ortamda matematiksel modelleme problemlerinin çözüm süreçlerinin analizi: Bilișsel ve üstbilișsel yapılar üzerine bir açılklama. Yayımlanmamıș doktora tezi, Dokuz Eylül Üniversitesi, İzmir.

Hıdıroğlu, Ç. N. ve Bukova Güzel, E. (2013). Teknoloji destekli ortamda matematiksel modellemede modelin doğrulanmasındaki yaklașımların ve düșünme süreçlerinin kavramsallaștırılması. Kuram ve Uygulamada Eğitim Bilimleri Dergisi (KUYEB), 13(4), 2487-2508.

Hıdıroğlu, Ç. N. ve Bukova Güzel, E. (2014). Matematiksel modellemede GeoGebra kullanımı: Boy-Ayak uzunluğu problemi. Pamukkale Üniversitesi Eğitim Fakültesi Dergisi, 36(2), 29-44.

Hıdıroğlu, Ç. N. ve Bukova Güzel, E. (2015). Teknoloji destekli ortamda matematiksel modellemede ortaya çıkan üst bilişsel yapılar. Turkish Journal of Computer and Mathematics Education, 6(2), 179-208.

Hıdıroğlu, C.. N. ve Bukova Güzel, E. (2016). Transitions between cognitive and metacognitive activities in mathematical modelling process within a technology enhanced environment. Necatibey Faculty of Education Electronic Journal of Science and Mathematics Education, 10(1), 313-350.

Hıdıroğlu, Ç. N. ve Bukova Güzel, E. (2017-Basımda). The Conceptualization of the Mathematical Modelling Process in Technology-Aided Environment. The International Journal for Technology in Mathematics Education, 24(1), ?-?.

Ikeda, T. ve Stephens M. (2001). The Effects of students' discussion in mathematics modelling. J.P. Matos, W. Blum, K. Houston ve S.P. Carriera (Eds), Modelling and mathematics education: ICTMA 9: Applications in science and techonology (ss. 381-390) içinde. Chichester: Horwood Publishing.

Janvier, B. D. ve Bednarz, N. (1987). Pedagogical considerations concerning the problem of representation. C. Janvier (Ed.), Problems of representation in the teaching and learning of mathematics (ss. 67-72) içinde. New Jersey: Lawrence Erlbaum Associates.

Ji, X. (2012). A quasi-experimental study of high school students' mathematics modelling competence. Paper presented at 12th International Congress on Mathematical Education Program, COEX, Seoul, Korea. 27 Haziran 2015 tarihinde http://www.icme12.org/ adresinden erișilmiștir.

Kaiser Meßmer, G. (1986). Anwendungen im mathematikunterricht. Bad Salzdetfurth: Franzbecker. 
Kaiser, G. (2005). Introduction to the working group "applications and modelling”. M. Bosch (Ed.), Proceedings of the Fourth Congress of the European Society for Research in Mathematics Education (ss. 1613-1622) içinde. Universitat Ramon Llull: FUNDEMI IQS.

Kaiser, G. (2007). Modelling and modelling competencies in school. C. Haines, P. Galbraith, W. Blum, ve S. Khan (Eds), Mathematical Modelling: ICTMA 12: Education, Engineering an Economics, (ss. 110-119) içinde. Chichester: Horwood Publishing.

Kaiser, G. ve Sriraman, B. (2006). A global survey of international perspectives on modelling in mathematics education. Zentralblatt für Didaktik der Mathematik, 38(3), 302-310.

Lamberts, K. (2005). Mathematical modelling of cognition. K, Lamberts ve R. L. Goldstone (Eds), Handbook of cognition (ss. 407-421) içinde. London: Sage.

Learning and Education in and through Modelling and Applications [LEMA], (2009). Booklet: Reality-based tasks for school. 08 Şubat 2017 tarihinde www.primas-project.eu/servlet/supportBinaryFiles?referenceId=3\&supportId=1245 adresinden erişilmiştir.

Lesh, R. ve Caylor, B. (2007). Introduction to special issue: Modeling as application versus modeling as a way to create mathematics. International Journal of Computers for Mathematical Learning, 12(3), 173-194.

Lesh, R. ve Doerr, H. M. (2003). Foundations of a models and modeling perspective on 3 mathematics teaching, learning, and problem solving. R. Lesh ve H. M. Doerr (Eds), Beyond constructivism: Models and modeling perspectives on mathematics problem solving, learning and teaching (ss. 3-34) içinde. Mahwah, NJ: Lawrence Erlbaum.

Lesh, R., Post T. ve Behr, M. (1987). Representation and Translations among Representations in Mathematics Learning and Problem Solving. C. Janvier (Ed.), Problems of representation in the teaching and learning of mathematics (ss. 33-40). New Jersey: Lawrence Erlbaum Associates.

Lingefjärd, T. (2012). Learning mathematics through mathematical modelling. Journal of Mathematical Modelling and Application, 1(5), 41-49.

Maaß, K. (2005). Modelling in class. What do we want the students to learn?. C. Haines, P. Galbraith, W. Blum, S. Khan (Eds), Mathematical Modelling: ICTMA 12: Education, Engineering and Economics, (ss. 63-78) içinde. Horwood Publishing, Chichester, UK.

Maaß, K. (2006) What are modelling competencies?. Zentralblatt für Didaktik der Mathematik, 38(2),113-142.

Magiera, M. T. ve Zawojewski, J. (2011). Characterizations of social-based and self-based contexts associated with students' awareness, evaluation, and regulation of their thinking during small-group mathematical modeling. Journal for Research in Mathematics Education, 42(5), 486-520.

Maki, D. ve Thompson, M. (2010). The mathematical modeling cycle. 25 Temmuz 2016 tarihinde http://www.indiana.edu/ hmathmod/modelmodel.html adresinden erișilmiştir.

Merriam, S. B. (2013). Nitel araștırma desen ve uygulama için bir rehber (S. Turan, Çev. Ed.). Ankara: Nobel Yayıncılık.

Miles, H. B. ve Huberman, A.M. (1994). Qualitative data analysis (2. Baskı). Thousand Oaks, CA: Sage.

Milli Eğitim Bakanlığı [MEB], (2013). Ortaöğretim matematik dersi (9-12. sınıflar) öğretim programı. Ankara: MEB Basımevi.

Montague, M. (2008). Math problem solving for middle school students with disabilities. 8 Mayıs 2016 tarihinde http://165.139.150.129/intervention/Math\%20Problem\%20Solving\%20for\%20Middle\%20School\%20Students \%20with\%20Disabilities.pdf adresinden erișilmiştir.

Mousoulides, N., Christou, C. ve Sriraman, B. (2006). From problem solving to modelling- A meta analysis. 26 Kasım 2016 tarihinde https://pdfs.semanticscholar.org/5ec1/10b0416eb038850354228eefb358fa715c85.pdf adresinden erişilmiştir.

National Council of Teachers of Mathematics [NCTM]. (2000). Principles and standards for school mathematics. 21 Eylül 2016 tarihinde http://www.nctm.org/Standards-and-Positions/Principles-and-Standards/ adresinden erişilmiștir.

Neria, D. ve Amit, M. (2004). Students preference of non-algebraic representations in mathematical communication. Proceedings of the 28th Conference of the International Group for the Pyschology of Mathematics Education, 3, 409416. 21 Ekim 2016 tarihinde https://www.emis.de/proceedings/PME28/RR/RR222_Neria.pdf adresinden erișilmiștir.

Niss, M. (2001). Issues and problems of research on the teaching and learning of applications and Modelling. J. F. Matos, W. Blum, S. K. Houston ve S. P. Carrera (Eds), Modelling and mathematics education (pp. 73-88) içinde. Chichester. Horwoord Publishing.

Organisation for Economic Co-operation and Development [OECD] (2003). Education at a glance: OECD indicators 2003. 11 Ekim 2016 tarihinde http://www.oecd.org/site/worldforum/33703760.pdf adresinden erișilmiștir

Organisation for Economic Co-operation and Development [OECD] (2016). Education at a glance 2016: OECD indicators. 11 Ekim 2016 tarihinde http://download.ei-ie.org/Docs/WebDepot/EaG2016_EN.pdf adresinden erișilmiştir.

Patton, M. Q. (1987). How to use qualitative methods in evaluation. Newbury Park, CA: Sage.

Patton, M. Q. (2002). Qualitative research \& evaluation methods (Third edition). Thousand Oaks, CA: Sage.

Peter Koop, A. (2004). Fermi problems in primary mathematics classrooms: Pupils' interactive modelling processes. I. Putt, R. Farragher ve M. McLean (Eds), Mathematics education for the third millenium: Towards 2010, Proceedings of the 27th Annual Conference of the Mathematics Education Research Group of Australasia, (pp. 454-461) içinde. Townsville, Queensland: MERGA.

Pólya, G. (1945). How to solve it: A new aspect of mathematical method. Princeton, USA, Princeton University Press.

Preston, R. ve Garner, A. S. (2003). Representation as a vehicle for solving and communication. Mathematics Teaching in The Middle School, 9(1), 38-44.

Punch, K. F. (2013). Sosyal araştırmalara giriş nicel ve nitel yaklaşımlar (2. Baskı). (D. Bayrak, H.B. Arslan ve Z. Akyüz, Çev.). Siyasal Kitabevi, Ankara. 
Saeki, A. ve Matsuzaki, A. (2011). Dual modelling cycle framework for responding to the diversities of modellers. G. A. Stillmann, G. Kaiser ve W. Blum (Eds), Proceedings of ICTMA15, Teaching mathematical modelling: Connecting to research and practice (pp. 89-99). Dordrecht, NLD: Springer.

Saeki, A. ve Matsuzaki, A. (2013). Dual modelling cycle framework for responding to the diversities of modellers. G. Stillman, G. Kaiser, W. Blum, ve J. Brown (Eds), Teaching Mathematical Modelling: Connecting to Research and Practice, (pp. 89-99) içinde. New York, USA: Springer.

Schoenfeld, A. H. (1985). Mathematical problem solving. Orlando: Academic Press.

Schwarz, B., Wissmach, B. ve Kaiser, G. (2008). 'Last curves not quite correct': Diagnostic compentences of future teachers with regard to modeling and graphical representations. ZDM Mathematics Education, 40(5), 777-790.

Stark, R. M. ve Nichols, R. L. (2005). Mathematical foundations for design: Civil engineering systems. Dover Publications.

Strauss, A. ve Corbin, J. (1990). Basics of qualitative research (1. Baskı). Thousand Oaks, CA: Sage.

Şen Zeytun, A. (2013). An investigation of prospective teachers' mathematical modeling processes and their views about factors affecting these processes. Unpublished doctoral dissertation, Middle East Technical University, Ankara, Turkey.

Tatsis, K. (2010). Assessing in-service teachers' modeling activities: Issues of content and complexity. The 17th annual conference of ALM adults learning mathematics - A research forum. Oslo, 28 June 2010.

Treilibs, V., Burkhardt, H. ve Low, B. (1980). Formulation processes in mathematical modelling. Nottingham, England: Shell Centre for Mathematical Education.Ang, K. C. (2001). Teaching mathematical modelling in Singapore schools. The Mathematics Educator, 6(1), 63-75.

Turner, R. (2007). Modelling and applications in PISA. W. Blum, P. Galbraith, H.-W. Henn ve M. Niss (Eds), Modelling and Applications in Mathematics Education, The 14. ICMI Study (ss. 433-440) içinde. New York: Springer.

Verschaffel, L., De Corte, E. ve Borghart, I. (1997). Pre-service teachers' conceptions and beliefs about the role of real-world knowledge in mathematical modeling of school word problems. Learning and Instruction, 7(4), 339-359.

Zawojewski, J. S., ve Lesh, R. (2003). A models and modelling perspective on problem solving. R. A. Lesh, ve H. Doerr (Eds.), Beyond constructivism: Models and modeling perspectives on mathematics problem solving, learning, and teaching (ss. 317-336) içinde. Mahwah, 